\title{
CARTOGRAFIA \& FOTOETNOGRAFIA DAS ÁGUAS: MODOS DE VIDA E DE LUTA NA AMAZÔNIA MARAJOARA
}

\author{
Agenor Sarraf Pacheco ${ }^{1}$
}

\section{Pelo Mundo das Águas: Itinerários}

Água que nasce na fonte/ serena do mundo/ e que abre um/ profundo grotão. Água
que faz inocente/ riacho e deságua/ na corrente do ribeirão...
Âguas escuras dos rios/ que levam/ a fertilidade ao sertão. Águas que banham aldeias/
e matam a sede da população...
(...)
Terra! Planeta Água. Terra! Planeta Água. Terra! Planeta Água. Guilherme Arante Planeta Água

Claras, escuras, de todas as cores, águas contadoras de histórias, memórias, práticas, saberes, modos de vida e de luta ${ }^{2}$ de mulheres e "homens anfíbios" esparramados entre rios, campos e florestas na complexa Amazônia Marajoara, no Pará. Ao longo das duas últimas décadas, 1995 a 2018, tenho me dedicado a trilhar diferentes percursos nesta região com o objetivo de compreendê-la melhor a partir do próprio ponto de vista, da cosmologia, modos de ser, fazer, acreditar, lutar, festejar, viver e morrer de seus habitantes (Geertz, 2009; 2012). Mediado por águas doces, salgadas, barrentas, esverdeadas, carregadas de limo, poluídas, reuni material variado para a tessitura de muitos enredos da experiência humana e não-humana (Ingold, 1995).

Pelos itinerários, procurei observar, conversar, fotografar, conviver e entrevistar mulheres e homens, idosos, adultos, jovens, adolescentes e crianças, social e etnicamente diferenciados. Junto disso, mergulhei em leituras e interpretei narrativas de cronistas, viajantes, literatos, historiadores e antropólogos, captando, quando possível, imagens, com destaque para fotografias, publicadas nestes escritos. Assim, fundamentado na hermenêutica sociocultural da História e da Antropologia, com destaque para os Estudos

\footnotetext{
${ }^{1}$ Universidade Federal do Pará, Brasil.

${ }^{2}$ A expressão "modos de vida e de luta" é cara aos Estudos Culturais Ingleses. Em diálogo com os estudos antropológicos britânicos, mas focalizando as sociedades modernas em processos de urbanização e industrialização, Raymond Williams mapeou a historicidade e os sentidos do conceito de cultura, entre os séculos XVIII ao XX, passou a compreendê-lo como "uma forma completa de vida, material, intelectual e espiritual" (1976:16), sem perder de vista "comportamentos simbólicos da vida cotidiana de uma comunidade" (Nelson, Treichler \& Grossberg, 2005:14). Já para Edward Palmer Thompson (1981: 189), as pessoas "experimentam sua experiência como sentimento e lidam com esse sentimento na cultura, como normas, obrigações familiares e de parentesco, e reciprocidades, como valores ou (através de formas mais elaboradas) na arte ou nas convicções religiosas". Tais práticas culturais se fazem sempre em experiências de luta em defesa de necessidades, interesses e expectativas. Assim, Stuart Hall (2003), ao apreender a perspectiva de Williams e Thompson, entende as práticas culturais como modos de vida e de luta em arenas assimétricas, desiguais, sociáveis e, muitas vezes, conflitivas.
} 
Culturais, Pós-Coloniais e Decoloniais, assim como para a Antropologia Interpretativa e Visual, venho esforçando-me para recompor, registrar e interpretar, ainda que fragmentariamente, um pouco dos modos como populações marajoaras vivem, trabalham, acreditam, lutam para resolver problemas do cotidiano em ecossistemas visíveis e sensíveis onde humanos, santos, orixás e encantados cruzam-se no fazer-se dos caminhos aquáticos, de várzeas e terras firmes amazônicas.

Nascido no mundo das águas de Breves, viajando sempre sobre este tapete líquido, depois que fui crescendo e tornei-me professor em Melgaço, acomodei-me nos elementos essenciais da existência de quem habita a região Amazônica e não problematizei e valorizei sua decisiva importância. Para poder desenvolver sensibilidades e processos de identificação e diferenciação nesses territórios insulares, precisei deixar esta terra e suas águas para olhá-la mais de perto, valorizar e compreender relações fundantes e estruturantes da existência e das condições materiais e simbólicas, potencialidades, dificuldades e contradições que lhes cercam.

A experiência de realizar estudos de pós-graduação em Minas Gerais e São Paulo, trabalhar em Belém na Universidade da Amazônia, entre 2008 a 2010, e, em seguida, na Universidade Federal do Pará, quando ingressar, em 2011, no Programa de Pós-Graduação em Antropologia e, em 2014, no Programa de Pós-Graduação em História Social da Amazônia, possibilitaram alargar olhares e modos de decifrar sentidos das experiências socioculturais que marajoaras alinhavam cotidianamente nas simbioses interculturais rural e urbano, oral e letrado, local e global, sob a regência, poder e sintonia das águas.

Nesse pluriverso, está o Marajó, cravado na foz do rio Amazonas e aberto ao Atlântico. Em sua porção ocidental, conforma-se pelo Marajó das Florestas, nos municípios de São Sebastião da Boa Vista, Curralinho, Bagre, Portel, Melgaço, Breves, Anajás, Afuá e Gurupá, e em sua porção oriental, constitui-se pelo Marajó dos Campos, nos municípios de Chaves, Soure, Salvaterra, Cachoeira do Arari, Santa Cruz do Arari, Muaná e Ponta de Pedras. A região é o maior arquipélago flúvio-marinha do mundo, com 16 municípios. Em 2017 apresentou uma população de mais de 500 mil habitantes, oriunda de matrizes indígenas, africanas, sem esquecer lusitanos, judeus marroquinos, entre outros grupos e nacionalidades, assim como nordestinos diversos (Leão, 2017). Os 50 mil quilômetros quadrados estão distribuídos em regiões de campos naturais, zonas de matas, praias, rios e mar, que dão espaços a cidades, vilas, fazendas, povoados, retiros, 
casas distribuídas irregularmente em longos espaços de rios, florestas, beira de estradas, em profunda conexão com o Maranhão, Belém, Macapá, Guiana Francesa, Caribe, municípios paraenses, outras regiões brasileiras, sem esquecer intercâmbios com o mundo, seja por meio de navios, balsas ou outras embarcações de grande porte que circulam pela região, seja em entradas e saídas de estrangeiros e moradores da região ou por meio do uso de novas tecnologias capazes de conectar os Marajós com o planeta.

O uso dos termos Marajó dos Campos e Marajó das Florestas ultrapassa a ideia de paisagem predominante nestes dois lados da região. Sua divisão é realizada em perspectiva geopolítica para marcar diferenças, semelhanças, relações históricas e culturais na constituição da região, pois em termos físicos, esses ambientes estão presentes em toda a Amazônia Marajoara. Ao longo dos últimos séculos, a região vem sendo interpretada como terra de grandes contrastes: de um lado suas riquezas humanas, arqueológicas e naturais, mas, pelos jogos do político e de interesses particulares de grandes latifundiários e empresários, foi soterrada em pobreza, reverberando diretamente na vida das populações, carentes de oportunidades de trabalho, formação escolar e profissional, além de condições para exercitar seu direito a uma existência digna e cidadã.

Nesse entendimento, o conceito de interculturalidade ${ }^{3}$ torna-se fundamental para leituras a contrapelo de experiências sociais desses agentes históricos que vivem em variados ambientes e habitares ao longo dos rios marajoaras. Em linhas gerais, a compreensão intercultural dos contatos entre diferentes pessoas ou grupos sociais centrase em sua capacidade de agência. Para isso, o vivido se faz no palco da cultura como arena de estranhamento, assimetria, diálogo, troca, cooptação, negação, contaminação, afetamento, conflito, sociabilidade, ressignificação e recriação à luz da cosmologia de grupos e pessoas em "zonas de contato" (Pratt, 1999).

$\mathrm{Na}$ explicitação de conceitos e encontros intersticiais, depois de leituras historiográficas, antropológicas e pesquisas de campo sobre indígenas, africanos, afrobrasileiros, mestiços e caboclos, passei a compreender as populações marajoaras etnicamente formadas em matrizes afroindíTgenas. A escolha pela categoria procura valorizar o ângulo dos marajoaras nas relações estabelecidas com colonizadores europeus e ibéricos, religiosos e outros sujeitos, tanto no período colonial, quanto em tempos contemporâneos. Inspirado em Deleuze e Guatarri (1995), Mignolo (2003), Roy Wagner

\footnotetext{
${ }^{3}$ Entre os diferentes autores que trabalham com a perspectiva intercultural, no que tange a mediações, tensões e contaminações entre agentes sociais diversos, sigo caminhos de Hall (2003), Bhabha (2003), Fleuri (2003) e García Canclini (2009).
} 
(2012), Goldman (2014) e Silva (2015), defendo a potência, criatividade e crítica que a categoria afroindígena carrega para se contrapor a gramáticas eurocentradas e exógenas de nominação do "outro" como tapuio, curiboca, cafuzo ou mesmo caboclo, os quais, em ângulo exógeno, desqualificam, silenciam ou essencializam processos de identificação das populações amazônicas e marajoaras (Gilroy, 2001).

Hoje, a historiografia afroindígena e a antropologia afroindígena, em suas posturas políticas, têm ganhado expressão no campo das humanidades, por isso uma diversidade de trabalhos acadêmicos dão conta desses mundos cruzados, sem negar as lutas por direitos do movimento indígena e do movimento negro ${ }^{4}$, assim como pelo reconhecimento de sua história, cultura, saberes e heranças na formação da nação brasileira $^{5}$. Aspecto que merece ser considerado nesse campo é a histórica experiência de conflitos vividos por indígenas, africanos e seus descendentes. É preciso não olvidar que o conflito foi uma arma da colonialidade utilizada pelos poderes estaduais e locais para que esses grupos étnicos não vivessem em redes de solidariedades (Gomes, 2005) e, com isso, colocasse a ordem colonial em ameaça.

A preocupação de tornar visível a proposta dos Marajós Afroindígenas, justificase pela presença de saberes indígenas e africanos em interconexão nas artes da vida, expressas em linguagens, afetividades, trocas de saberes, astúcias e religiosidades praticadas fortificações, pesqueiros, roças, fazendas, habitações, terreiros, quilombos e mocambos construídos na região (Sarraf-Pacheco, 2010). Não por acaso, na parte do Marajó do Campos, como Soure, Salvaterra e Chaves, seja em seu meio rural ou centro urbano, ainda hoje, curandeiros, benzedores, pajés, pais-de-santo reatualizam rituais de cura por meio de "orações fortes", batidas de tambores, jogos de búzios, in vocações de caruanas como entidades das águas, do ar, da terra e das florestas, para livrarem corpos de seus semelhantes de adversidades físicas, mentais, sociais e espirituais ${ }^{6}$, como se

\footnotetext{
${ }^{4}$ É preciso não perder de vista que os termos "índio e negro", no contexto da colonialidade do poder, foram, conforme Quijano citado por Mignolo (2003:85), identidades forjadas para homogeneizar e apagar a diversidade das identidades "india" e "negra".

${ }^{5}$ No repertório bibliográfico sobre a categoria analítica, merece destaque: Sarraf-Pacheco (2009; 2016); Silva e Sarraf-Pacheco (2012); Goldman (2014). Pista para historiadores e antropólogos pensarem nos mundos cruzados, sem esquecer diferenças, assimetrias e estratégias colonizadoras para colocar indígenas contra africanos no Brasil durante e depois do período colonial, entre outras, emergem nos estudos de Pereira (1952) e Bastide (1974).

${ }^{6}$ Em parceria com o amigo e professor Jorge Paulo dos Santos Watrin, escrevemos o projeto: Vaqueiros, pescadores, curandeiros e pais-de-santo: formas de trabalho e práticas culturais no Marajó dos Campos, desenvolvido junto à turma de alunos do curso de Licenciatura e Bacharelado em História/UFPA, Campus Universitário de Soure, no período de 17 a 27 de julho de 2007. No acompanhamento das pesquisas,
} 
acompanha nos outros municípios de floresta, mesclando o poder curativo da medicina popular com o da medicina científica ${ }^{7}$.

No âmago desses percursos, neste artigo, cartografo $^{8}$ repertórios de narrativas escritas, visuais e orais sobre viveres no regime das águas marajoaras, traduzidos em saberes, práticas de trabalho, modos de habitar, acreditar, lutar e se relacionar das populações de matrizes afroindígenas. Exploro vivências e leituras sobre a região, cruzando com fotografias produzidas em pesquisa de campo, realizada em agosto de 2008, ou extraída do etnólogo Nunes Pereira (1956), do cineasta Liberto Luxardo (1977) e do padre Giovanni Galo (1980, 1981), que, entre as décadas de 1950 a 1980, dedicaramse a estudar o grande arquipélago para compreender como, nesse pedaço da Amazônia, homens e mulheres de etnicidades diversas, agenciados pelas águas, continuam lutando para preservar tradições ${ }^{9}$, imaginários, saberes e crenças em intensas interfaces com emergentes ações de poderes locais, defensores da razão ocidental em expansão.

A reconstituição de espaços de trabalho, celebração e lazer analisados sofrem reconfigurações permanentes, dada a entrada na região de equipamentos de culturas globais, os quais seduzem à uniformização de costumes, atitudes e modos de ser, estar e viver em ambientes locais (Williams, 1969; Hoggart, 1973; García Canclini, 2000; Mignolo, 2003). Nesses processos de mudanças e dinâmicas culturais, marajoaras passam a operar com outras ferramentas, algumas tencionadas pela expansão de linguagens e propagandas de uma cultura midiática ${ }^{10}$ a exigir elaborações de outros códigos comunicacionais para melhor situarem-se nos ambientes sociais de rios, cidades e florestas (Martín-Barbero, 2001; Hall, 2003). Estes, por sua vez, como agentes de sua

sustentadas por depoimentos orais de moradores da cidade, percebemos a longa tradição no sistema de crenças em entidades do mundo da encantaria afroindígena e do catolicismo ibérico na região.

${ }^{7}$ É vasta a literatura sobre o tema na Amazônia, entre os estudiosos cito: Maués (1990; 1995); Vergolino e Silva (2015) [1979], (2003); Figueiredo (2003; 2009) e Prandi (2001), Silva (2014).

$8 \mathrm{Na}$ perspectiva de Deleuze e Guattari (1995), Martín-Barbero (2004), Edouard Glissant (2005), Boaventura Santos (2010) e Homi Bhabha (2003), a Cartografia é um campo teoricometodológico que procura cruzar teoria e empiria sem hierarquizações, disciplinaridades e cronologias fechadas. Por isso, pelos labirintos dos saberes históricos e antropológicos, atenho-me em rotas abertas ao diálogo com a imprevisibilidade e o improviso da vida real e simbólica.

9 Apreendo o termo tradição como algo que, ao caminhar em constante processo de atualização, dialoga com dimensões de viveres residuais e emergentes (Williams, 1969). Importa não esquecer que essas tradições criam ritmos, modos de vida e processos de incorporações/adaptações/preservações diferenciadas (García Canclini, 2001; Hall, 2003).

${ }^{10}$ Martín-Barbero (2001:28) contribui para se avançar como o espaço das comunicações constitui-se em territórios em processos amalgamados de imagens, interesses e perspectivas de mestiçagens, diria afroindigenidade, entendidas não apenas como fato racial, mas como um conjunto de tramas e descontinuidades culturais, deformações sociais e estruturas do sentimento, de memórias e imaginários que misturam o rural com o urbano, o sagrado com o profano e o popular com o massivo. 
própria história, praticando uma espécie de razão decolonial (Miglievich-Ribeiro, 2014), reelaboram orientações exógenas, incorporam, são cooptados, recriam e reinventam objetos e formas de vida em consonância com sensibilidades e espiritualidades de seus sentidos.

As fotografias recuperadas e analisadas em simbiose com observações, clics, entrevistas e documentos escritos desvelam cenas de um viver marajoara atravessado pela dinâmica das águas. Com base nesses acervos e no conhecimento do campo dos estudos imagéticos, produzido por historiadores e antropólogos, apreendo a fotografia como repleta de intencionalidade, legitimadora de cosmovisões e relações de poder de um determinado momento histórico (Kossoy, 2000; Mignolo, 2017; Foucault, 1979). Cabe ao pesquisador "decifrar a realidade interior das representações fotográficas, seus significados ocultos, suas tramas, realidades e ficções, as finalidades para as quais foram produzidas" (Kossoy, 2000:22-23).

Para Boni e Moreschi (2007), a utilização da fotografia em pesquisas antropológicas alcança variados objetivos. Entre eles, o instante congelado da cultura em movimento permite surpreender mudanças e continuidades nos modos de vida e de luta de uma sociedade ou grupo étnico específico. Um conjunto de imagens produzidas pelo antropólogo ou por ele catalogado de outros acervos particulares ou públicos, na perspectiva da Antropologia Visual, ajuda a adentrar em zonas de silêncio da cultura para se desadormecer vozes, saberes e práticas que se deseja conhecer e colocar em circulação.

Nesse exercício, Mignolo (2003) e Boaventura Santos (2010) são esclarecedores ao discutirem o papel do intelectual que escreve nas linhas do pensamento pós-colonial e decolonial quando assinalam a necessidade de trazermos de volta à praia histórias, agentes, memórias e saberes que foram subalternizados e apagados pela ciência moderna. Assim, a fotoetnografia, enquanto proposta metodológica, contribui para religar, por dentro do fazer científico, conhecimentos que foram hierarquizados e ocultados, deixando ver a ecologia de saberes, proposta por Boaventura Santos (2007), como alternativa política e ética para se estudar ecossistemas culturais de uma região como a marajoara, valorizando a interculturalidade, a diversidade e o respeito à diferença étnica, de gênero, de classe e religião. Nesse sentido,

Valeria a pena debruçar-se melhor sobre a natureza dessa eclosão conjunta Antropologia e Fotografia - em meados do século passado - que têm uma vocação comum: a de tentar revelar os homens e as sociedades, suas paixões, seus delírios, seus imaginários (Meneses, 1995:28). 
O poder e a agencia da imagem molda sensibilidades, posturas e atitudes de observadores e intérpretes frente à realidade social. Igualmente ela tem a capacidade de revirar o baú de memórias de experiências passadas, na maioria das vezes escondidas nos quadros do esquecimento involuntário, contribuindo para que a pessoa traga à tona outras reminiscências da existência física e simbólica num processo de releitura capaz não apenas de avaliar o passado, mas também renovar esperanças para o futuro.

Antes de a fotografia se popularizar e ganhar lugar de destaque nas pesquisas em humanidades, historiadores da arte já exploravam as imagens pictóricas em suas investigações. Atentos à dimensão estética, plástica e/ou estilística, estes estudiosos revisitaram o passado e explicitaram tendências, especificidades, características e ligações com o presente das sociedades contemporâneas (Giannotti, 2005). Não por acaso, a grande produção científica sobre o trabalho com as imagens ou mesmo com a fotografia não está no currículo de historiadores e antropólogos, sem deixar de reconhecer o trabalho pioneiro dos historiadores da arte.

Granet-Abisset (2002:10) ao rever a historicidade dessa confecção, assevera que os semiólogos, preocupados com os "elementos técnicos e estéticos assim como a análise da imagem em si mesma", saíram na frente e têm construindo importante legado para o entendimento do lugar da imagem na formação humana. Certamente, o modo de trabalhar com as imagens e, especialmente, com a fotografia possui semelhanças e muitas diferenças entre historiadores da arte, semiólogos, historiadores e antropólogos. A longa tradição da Antropologia no estudo das sociedades ocidentais e orientais ganhou novos contorno com a cultura visual, com destaque para "a natureza construída do olhar e das formas de expressão e comunicação visual” (Campos, 2012:20).

Toda narrativa seja ela oral, escrita ou visual é comunicação, repertório de saberes e conexão para o entendimento dos modos de vida e de luta de povos e culturas em espaços e tempos situados. A historiadora francesa Anne Marie Granet-Abisset (2002) explica que o rigor da escrita da história requer do pesquisador da fotografia rastreio do maior número de evidências do passado em investigação. "O confronto com outras fontes, orais e escritas, administrativas e privadas, é também condição fundamental para ressaltar, ao mesmo tempo, a especificidade da contribuição da fotografia e extrair verdadeiras análises" (Granet-Abisset, 2002:24) da temática de pesquisa estudada.

A preocupação com as pistas do passado não é específica do trabalho do historiador. Toda boa etnografia, entendida com cruzamento entre teoria e empiria, 
conforme defende Mariza Peirano (2014; 2016), é um grande palimpsesto de saberes em inter-relações. Geertz (2012) é categórico nessa direção quando assinala que a antropologia é um recurso de erudição. Já Michel Fischer (1980) assinala que as categorias culturais nativas, apreendidas na pesquisa de campo, só ganham sentido para a ciência antropológica se forem compreendidas sociológica e historicamente, pois é neste exame que se pode identificar mudanças e continuidades no sistema cultural de uma determinada sociedade.

No entanto, diferente das orientações de Granet-Abisset (2002), o trabalho do fotógrafo e antropólogo Luiz Eduardo Robinson Achutti (1997) parte da ousadia de analisar fotografias nos caminhos da fotoetnografia, valorizando sua própria linguagem, trajetória, capacidade de comunicação. Nessa simbiose, Etienne Samain (1995) em diálogo com Margareth Mead (1975) explicam que o antropólogo contemporâneo precisa ultrapassar falas e discursos acerca de práticas culturais de mulheres e homens em exercício descritivo e analítico. É preciso agora deixá-los ser visto em sua plenitude.

\section{Modos de Vida e de Luta em Textos e Imagem}

Pluralidade de leituras e de interpretações, mas também, inicialmente, pluralidade de olhares e de intenções. Estabelecer relações entre várias fotos sobre um mesmo tema, tomadas a partir de lógicas diferentes, é sempre muito interessante (Granet-Abisset, 2002:18).

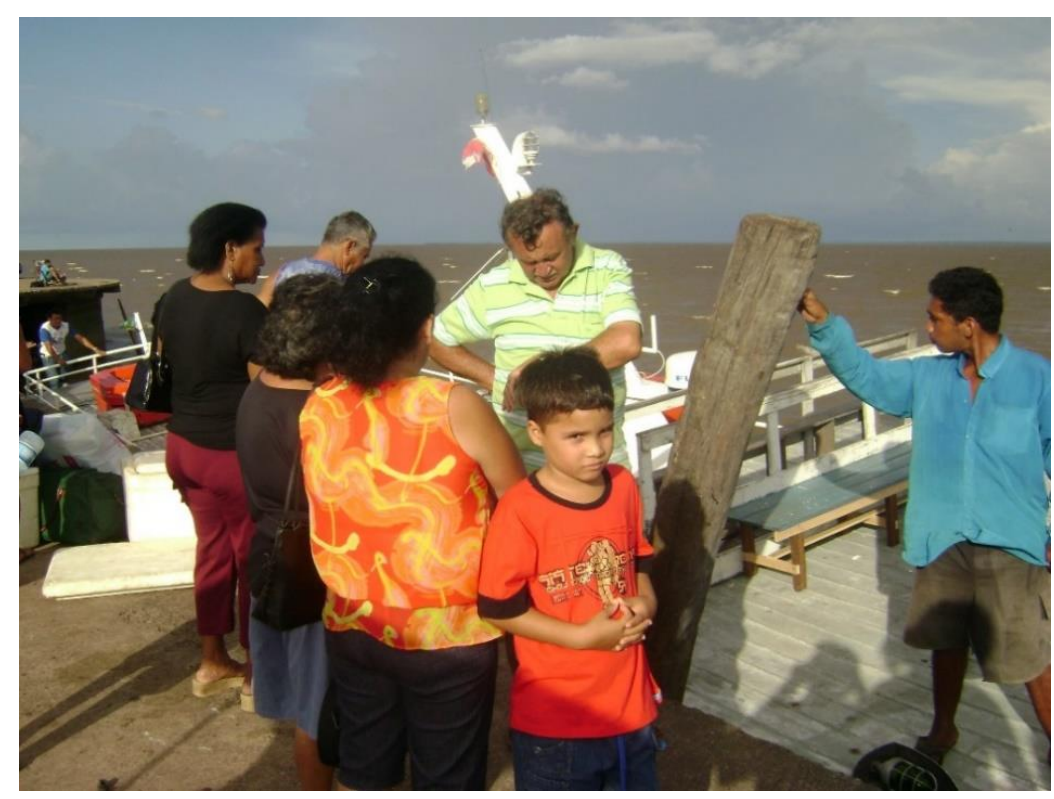

Foto 1. Porto de Macapá-AP, pessoas à espera da enchente. O olhar de um dos passageiros ao relógio indica que o tempo e o planejamento do homem e da mulher amazônicos que precisa dos rios para encaminhar sua vida, devem ajustar-se ao relógio das águas. Pesquisa de Campo, agosto de 2008. 
Como é a vida numa região em que os caminhos são rios e os principais transportes para se ir a um lugar são cascos, rabetas, rabudos, barcos, voadeiras, lanchas, navios, balsas? No porto de Macapá em agosto de 2008, quando parti de Belém para alcançar os municípios de Afuá e Chaves, no norte do arquipélago de Marajó, fronteira de campos e florestas, a indagação tomou contou de meu universo de preocupações. Seguindo orientações de historiadores e antropólogos da imagem, a partir de agora, recomponho essas experiências e adentro nos modos de viver, trabalhar, lutar e acreditar na região em cenas visuais e escritas.

Mulheres, homens, idosos, adultos, jovens, criança de etnicidades diversas, com destaque para a presença negra e afroindígena, encontram-se em agosto de 2008 em um dos portos da cidade de Macapá, no estado do Amapá, conforme se observa na foto (1). O objetivo era tomar a lancha para viajar à cidade de Afuá. Apesar de ser um homem anfíbio, como poderia dizer o padre jesuíta João Daniel (2004) ou o cineasta, jornalista e escritor, Líbero Luxardo (1977), porque nasci, cresci e continuo a viver em enormes espaços marcados pelo colorido de muitos rios e florestas, os percursos para visitar realidades marajoaras nem sempre foram fáceis. A pluralidade de realidades físicas, humanas, sociais e energias espirituais que perfazem os dezesseis municípios do arquipélago, especialmente quem habita na parte florestal e precisa chegar aos campos, faz da Amazônia Marajoara, um país “estrangeiro" para seus próprios habitantes. Certamente, muitos marajoaras não conhecem os Marajós.

Ciente e conhecedor do regime das águas doces da região de florestas, embaralhei-me completamente quando fui conhecer a contra-costa, nas temporalidades que envolvem Afuá e Chaves. Semelhante a negros em fuga das Guianas para aquele Marajó ou vice-versa, entre os séculos XVIII e XIX (Gomes, 2005), viajantes estrangeiros que quiseram conhecer a região no século XIX, subindo ou descendo da América do Sul (Araújo, 2017) ou religiosos agostinianos espanhóis, quando assumiram, em 1946, a direção da paróquia de Afuá e incorporaram Chaves, para evangelizar naquela vasta plaga, enfrentando águas do Amazonas em seu encontro com águas do Atlântico, na fronteira Pará/Macapá, eu era mais um estranho em fronteiras. Desse modo, na viagem que realizei a Chaves para conhecer a cidade, encontrar alunos do Projeto Por Campos $e$ Florestas $^{11}$, pesquisar na paróquia e entrevistar alguns moradores, vivi uma grande e

\footnotetext{
${ }^{11}$ Este projeto foi escrito pela arqueóloga Denise Schaan e aprovado pelo CNPq. Seu objetivo consistiu em capacitar professores marajoaras para realizarem pesquisas de campo em suas realidades, explorando as temáticas do patrimônio, arqueologia e outras expressões culturais. A convite desta pesquisadora, tornei-
} 
perigosa aventura. Para chegar àquela cidade, precisava viajar primeiro a Macapá, tomar uma lancha para Afuá e, finalmente, dentro de outra embarcação, poder pisar no porto daquela terra dos antigos e temidos Aruãs.

Aparentemente era um percurso tranquilo. Julgando-me experiente em viagens, rumei de avião de Belém para Macapá. Quando cheguei àquela desconhecida capital foi que tomei conhecimento das dificuldades para completar a rota almejada. Depois de saber o local e o provável horário da lancha que sairia para Afuá, na hora marcada corri para o porto.

Quando cheguei, percebi que a embarcação estava no seco e as pessoas esperavam a autorização para o embarque (Foto 1). Curioso em querer saber o real horário que sairíamos, indaguei a um senhor, tripulante da lancha, ele então me falou: - "Quando a maré crescer, viajaremos!" Mesmo em pleno século XXI, numa era dos mais criativos empreendimentos tecnológicos de comunicação e transporte, a Amazônia e seus Marajós estavam profundamente conectados e dominados pelo regime das águas.

Daí passou meia, uma, duas horas para que a "maré crescesse e desse no barco", permitindo-nos cortar as águas do Cabo Norte, rumo ao corredor da antiga "Ilha Grande de Joanes". Na travessia pelo famoso e temido canal do Vieira, local onde os padres agostinianos viveram, em décadas passadas, momentos de tormento, medo e solidão, a ventania foi tão forte que quebrou a vidraça protetora do barco.

Em Afuá, depois de conhecer a incrível cidade sobre pontes, conversar com diferentes moradores, produzir uma dezena de fotografia da Veneza Marajoara, realizar a pesquisa na paróquia, ler e xerocar o Livro de Coisas Notáveis e outros materiais impressos, além de entrevistar o pároco da Paróquia N. Sra da Conceição, frei Cleto Millán, procurei saber como poderia ir a Chaves. Indicaram-me que um senhor tinha uma rabeta, pequeno barco com motor de popa sem cobertura. Por intermédio de alguns interlocutores, cheguei ao proprietário e motorista da embarcação com um motor de 18 Yamaha B18. Quando acertei o preço e perguntei a hora, ele comunicou -me que sairíamos às 5h00 da manhã para não pegarmos as fortes ondas na contra-costa do arquipélago.

me vice-coordenador do projeto e pude acompanhar as três principais etapas de seu desenvolvimento: o curso de educação de professores pesquisadores; a pesquisa de campo; e a oficina de produção textual. O resultado do projeto gestou dois livros didáticos, um para o Ensino Fundamental Maior e o outro para o Ensino Médio, que foram distribuídos gratuitamente às escolas públicas da região. Ver: Schaan, SarrafPacheco e Beltrão (2011) e Sarraf-Pacheco, Schaan e Beltrão (2012). 
Por certo, saímos no horário marcado, mas os ventos atlânticos fizeram o Amazonas ficar embravecido em fortes ondas, antes de chegarmos ao destino marcado. Resultado, a viagem presenteou-nos com um grande e longo banho.

Ao aproximarmos de Chaves, já encolhidos de tanto frio, vi que o motorista não encaminhou a rabeta para o longo e caneludo trapiche principal, o hidroviário da cidade. Ele entrou por um igarapé que alcança o fim da rua principal daquele histórico espaço urbano.

Todo molhado, caminhei pela desconhecida cidade em busca de um hotel. Enquanto andava por aquela rua, uma professora, participantes do projeto Por Campos e Florestas, enxergou-me e riu como se me dissesse: - Agora o senhor experimentou e conheceu o Marajó dessas bandas de cá.

A experiência destas viagens, somada às que realizei para Soure e Salvaterra, quando senti as fortes pancadas provocadas pela baia de Marajó em navios da linha Belém-Camará, permitiu apreender e ver como os Marajós não são diferentes apenas fisicamente, pois pessoas que habitam esses espaços também apresentam outras maneiras de ser, expressar-se e se relacionar-se com humanos e não-humanos.

As diferenças, contudo, não apagam semelhanças e intercâmbios. Mesmo que o trânsito de pessoas, ideias, cultura material entre os municípios marajoaras banhados pelo rio Amazonas seja intenso com Macapá e os municípios banhados pelo oceano Atlântico, baia de Marajó e Rio Pará, seja mais forte com Belém, marajoaras de Soure e Salvaterra, por exemplo, visitam Portel, Melgaço ou mesmo Afuá e o distante município de Chaves, daquele ponto de partida. 


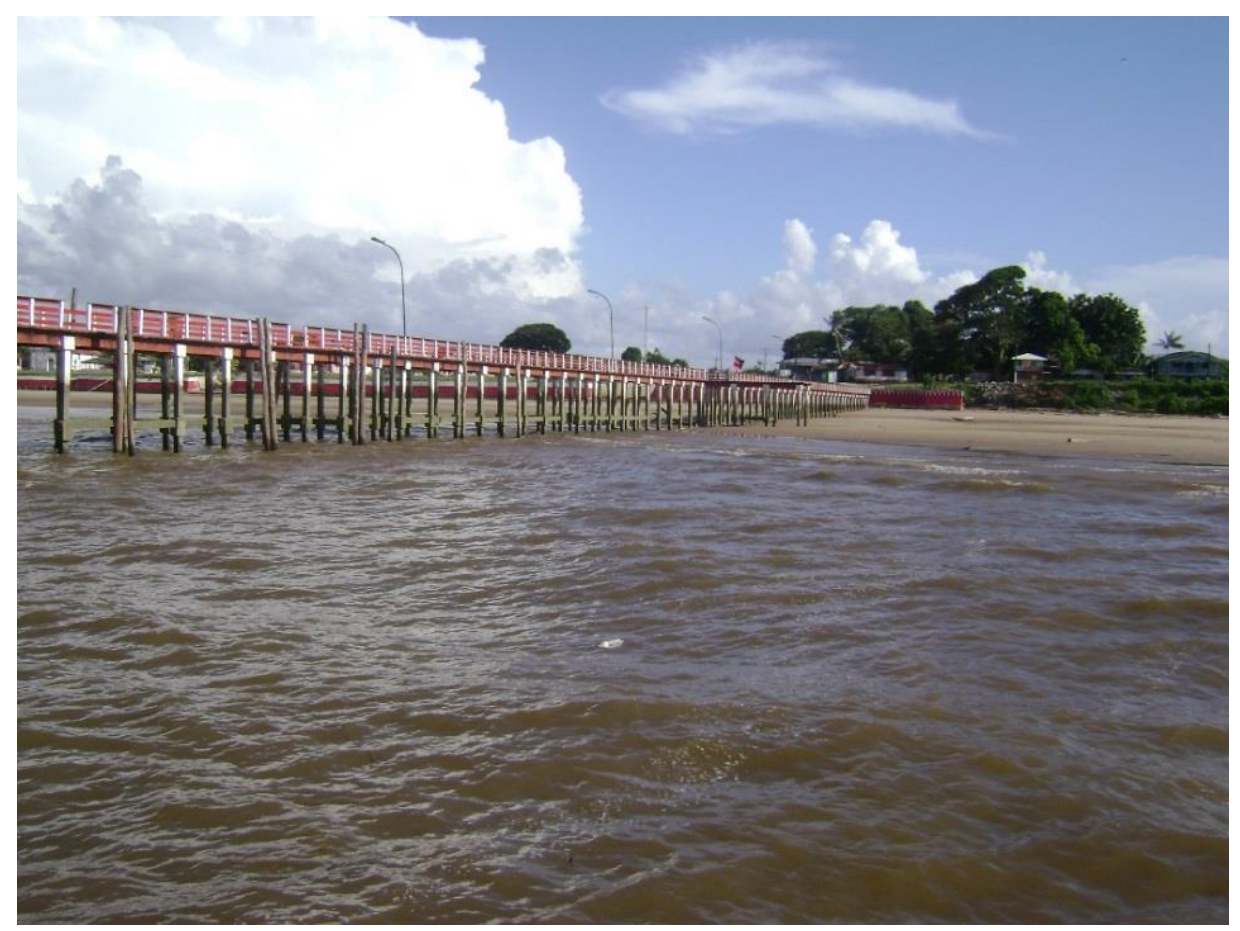

Foto 2. Trapiche municipal, porta de entrada à cidade de Chaves. As necessidades de comunicação mulheres, homens e águas mais profundas, depois que parte do terreno foi destruído pelas temerosas ondas a reverberar no rosto da terra dos Aruãs, justificam sua construção. Pesquisa de Campo, agosto de 2008.

Envolvidos em outros padrões culturais e mediações rios e florestas, invisíveis e incompreensíveis para olhares estrangeiros, habitantes do reino das águas marajoaras desestabilizaram referências de ambientes que perderam suas coberturas vegetais e tornaram-se sociedades de concreto. Na dinâmica marajoara, populações locais sempre sensíveis e sintonizadas aos mistérios da floresta amazônica, produziram inteligíveis modos de vida, trabalho e luta, os quais vêm lhes permitindo dialogar e respeitar temporalidades dos indissociáveis reinos: humano, vegetal, animal e mineral garantidor do sustento de seu dia-a-dia ${ }^{12}$.

O poder exercido pela pororoca sobre a vida humana, vegetal, animal, mineral, assim como nas relações dos moradores com encantados e caruanas, altera a paisagem e os sentidos de se viver em Chaves. Em leituras de crônicas religiosas e conversa com padres e bispos que navegaram por esta região todos foram unânimes em afirmar como este fenômeno natural, da mesma forma em que seca baias e traga ilhas inteiras, também

12 Como povos de tradições orais originários dos mundos afroindígenas, populações marajoaras e amazônidas construíram sentidos para mundos visíveis, assentados em interconexões com reinos da natureza e suas pujantes forças invisíveis. Inspiração para esta elaboração vem de Hampâté Bâ (2012). Sobre estas questões em contexto brasileiro, ver, por exemplo, Antonacci (2009). 
entope e abre extensos canais por meio das matas. Conforme Frei Faustino, ao redor da ilha Caviana, corredor daquela feroz passagem, crescem inúmeros e extensos campos, quase duplicando seu tamanho (Legarda, 1959, p. 48).

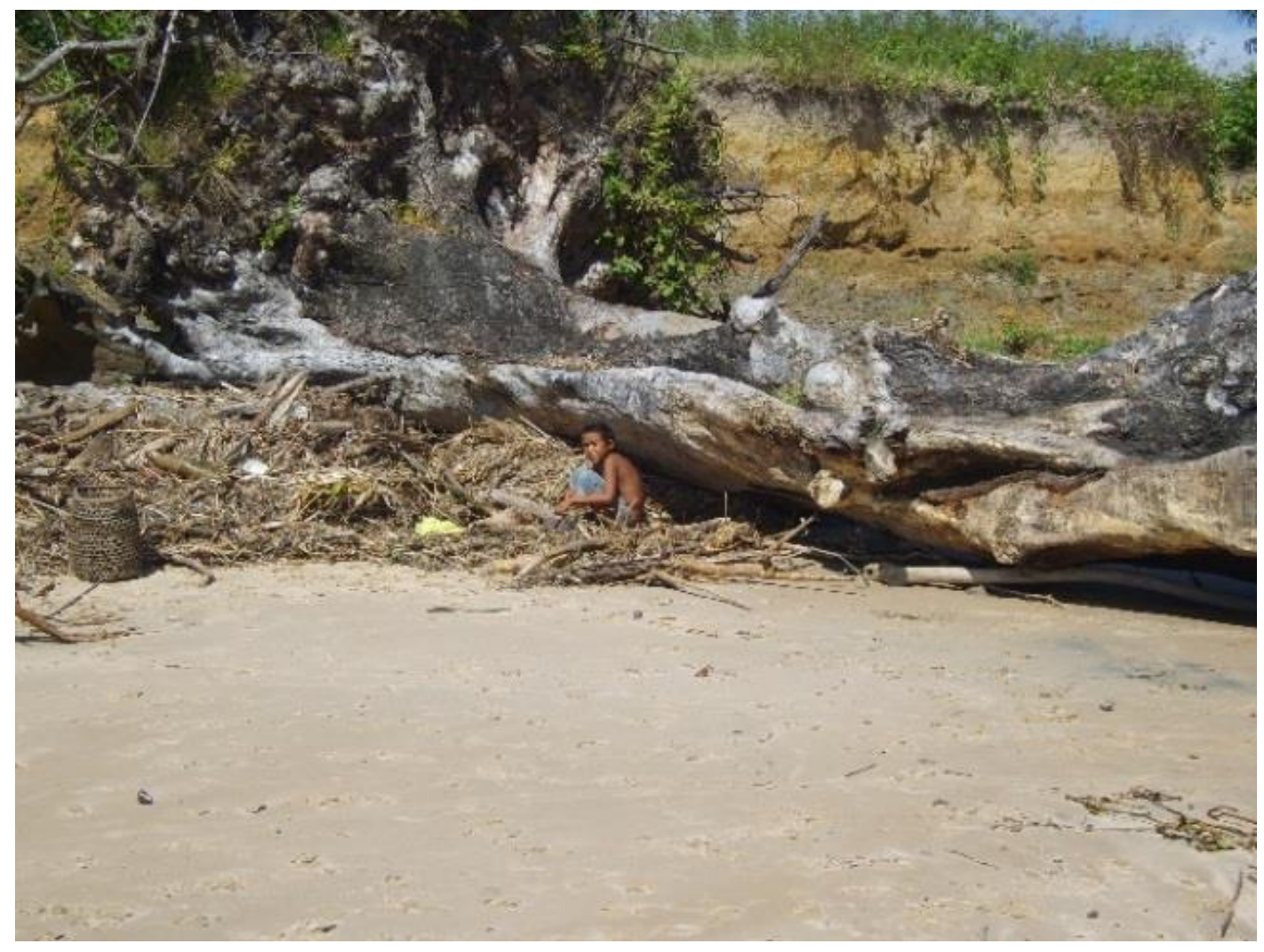

Foto 3. Parte da orla da cidade de Chaves com sua vegetação destruída pelo processo erosivo causado pelo encontro rio-mar. Nos últimos anos tornou-se em espaço para brincadeiras diversas entre as crianças de descendências afroindígenas como o tradicional esconde-esconde. Pesquisa de Campo, agosto de 2008.

A própria cidade de Chaves e seus moradores são moldados pelos encontros de salgadas águas do Atlântico com doces e barrentas águas do Amazonas. Na visita de agosto de 2008, chamou a atenção o enorme trapiche e a imensa praia formada em frente ao pequeno núcleo urbano. Em conversa etnográfica com alunos da Universidade Federal do Pará, participantes do Projeto "Remando por Campos e Florestas" e moradores do lugar, fiquei sabendo que o rio já engoliu uma boa parte do povoado.

Nos passeios que fazem pela praia, comumente, seus habitantes encontram os mais diversos tipos de artefatos coloniais, inclusive imagens sagradas como as recuperadas pelos professores do "Remando por Campos e Florestas" (Foto 4). Essa experiência deixa ver a forte relação cultura e natureza e o poder da natureza de soterrar 
a cultura material utilizada pelas populações tradicionais. Nestes territórios da cultura, a arqueologia é campo indispensável para escavar a vida no passado recente.

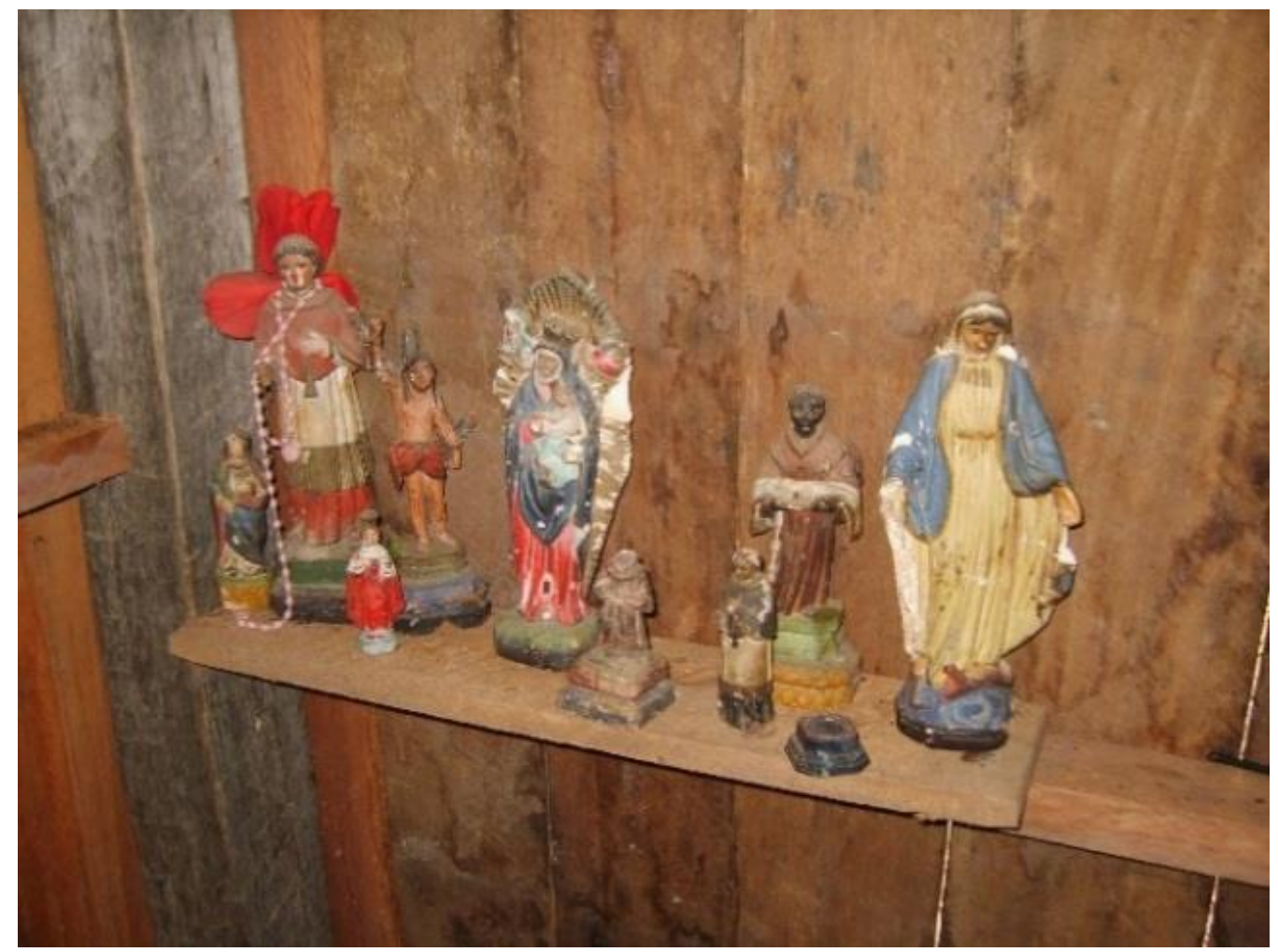

Foto 4. Santos domésticos como Santo Antônio, São Sebastião, N. Sra do Perpétuo Socorro, N. Sra da Conceição, São Benedito, entre outros, recuperados na orla da cidade, tragada pelo corpo-a-corpo margens e poder das águas. Tais suportes sagrados, já deixam ver sinais da visível religiosidade devocional de Chaves. Pesquisa de Campo, agosto de 2008.

Josebel Fares em diálogo com diferentes estudiosos amazônicos que abordaram em suas narrativas o papel desempenhado por essa imensa massa de água na vida de gentes situadas no vasto estuário, entre eles apresenta apreensões de Raymundo Moraes. Para este intelectual dos anos de 1930, a água é relógio da Amazônia, porque ela não "marca somente as horas, as semanas, os meses e os anos, mas a escassez e a fartura, a alegria e a tristeza. É na corrente dos rios e na superfície dos lagos, que se decidem nossos problemas. De maneira que o homem, em vez de consultar a marcha dos astros na decifração dos enigmas, consulta a altura das águas” (Morais, 1936:257 apud Fares, 2003:31).

Raymundo Moraes, "talvez o mais solitário e prolixo dos escritores amazônicos das décadas de 1920 e 1930”, conforme Figueiredo (2003:273), criador da metáfora águas como relógio da Amazônia e do rio como rua, também pensou a região como um 
anfiteatro, por ter suas histórias divididas entre narrativas que a evidenciaram e narrativas que a puseram na penumbra, numa clara relação com a leitura decolonial, atenta às histórias das margens. Em artigo redigido em 1936, trouxe cotidianos de habitantes do furo de Breves em mediações águas e embarcações.

Ninguém se transporta de um sítio a outros do encantado meandro, por mais perto que seja, senão no banco das montarias esguias, asseadas, ligeiras. Rema-se à proa, remase à meia-nau, rema-se à ré. A sociedade simples dos seringueiros, na prática natural da reza, dos enterros, das missas, transporta-se na piroga. Os defuntos vão pra cova embarcados, embarcados vão os noivos, os padeiros, as procissões, os caçadores, os comerciantes, os trabalhadores, os eleitores, os namorados, os músicos. O rio é a rua. Floresta adentro, mesmo no verão, a terra é úmida, plástica, como se estivesse nos primeiros dias moles do Gêneses (Moraes, 1936:60-61).

Nessa mesma linha de pensamento, Giovanni Gallo - padre italiano e jesuíta, que em 1973 passou a residir em Genipapo, município de Santa Cruz do Arari, pertencente à Prelazia de Ponta de Pedras -, em diferentes passagens de seus textos, narrou observações, experiências e compreensões sobre a força desempenhada pelas águas na vida marajoara e como seus habitantes interagiram neste contexto.

O título de sua primeira obra sobre a região, - Marajó: a ditadura das águas -, fruto de artigos escritos entre os anos de 1973 a 1980, e publicados nos Jornais O Liberal e $O$ Estado do Pará, traz expressivos dados etnográficos dos poderes que este patrimônio mundial desempenha no dia-a-dia e no futuro da região (Gallo, 1981) ${ }^{13}$.

\footnotetext{
${ }^{13}$ A trajetória de padre Gallo inicia-se, em 1973, no Marajó dos Campos, na vila Jenipapo, município de Santa Cruz do Arari. Depois de vivenciar com marajoaras experiências de pesca em alto-mar, deparou-se com uma infinidade de artefatos arqueológicos existentes na região. Muitas vezes, no lugar de peixes, o padre e os pescadores capturavam pedaços da ancestral cerâmica marajoara. Preocupado com a preservação desses fragmentos culturais e acreditando ser este um caminho para a emancipação das populações locais, ele decidiu construir, com ajuda dos moradores de Jenipapo, um espaço para guardar e expor suportes materiais que permitissem leituras e estudos das culturas marajoaras. Em meio a seus empenhos e dificuldades frente a poderes locais, o religioso conseguiu erigir o primeiro Museu do Marajó, criação que potencializou diferentes estudos sobre a vida na região de campos, contatos com intelectuais do centro-sul do país, norte-americanos e de outros continentes.
} 


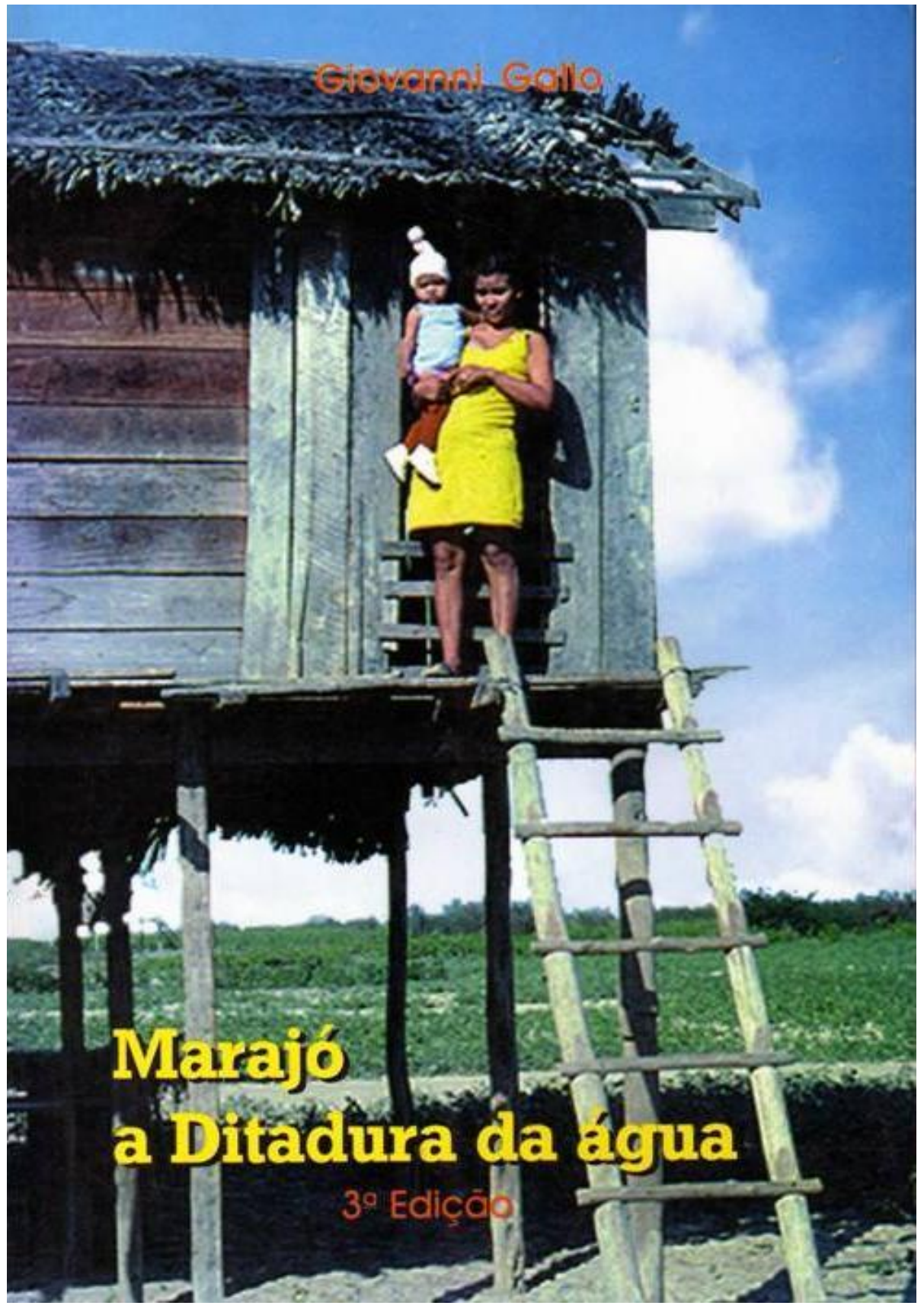

Foto 5. Nesta imagem, padre Gallo (1981) destaca habitações em estilo palafita, próprias ao enfrentamento dos perigos de submersão nas fortes cheias. Um saber local para lidar com a dinâmica da invernada e terroada marajoara, quando a terra fica seca e racha, é uma leitura possível. 
Em entrevista a Josebel Fares e José Guilherme Fernandes, concedida em 2001, padre Gallo inventor do singular computador marajoara, em seu museu artesanal, cujas peças foram expostas para serem tocadas e manuseadas, identificou a água como reguladora de vidas. Baseado em suas experiências no Marajó dos Campos, falou dos tempos de cheias e secas, condicionadores do jeito de ser e de se colocar no mundo daquelas populações. Recuperando o significado da foto com a casa caneluda, capa que abre a $3^{\text {a }}$ edição de seu livro, Gallo permite ver adequações realizadas por marajoaras para equilibrarem-se naqueles espaços que, em tempos de cheias, parecem flutuar sob as ordens da maré e, no período de secas, transformam-se em ambiente de dois andares.

Um mergulho no universo de mulheres e homens anfíbios ${ }^{14}$, em seus modos de vida e relações socioculturais, ajuda a desvendar astúcias para lidar com a geografia dos rios, a corrente dos ventos e suas ações nos abrolhos de solos assoreados, construindo específicas experiências históricas. No Marajó dos Campos, por exemplo, os criatórios de gado fizeram índios, negros e seus descendentes inventarem formas para lidar com a dura faina dos períodos de maré alta e maré baixa.

Em tempos alagados, braços negros e afroindígenas construíram aterros, marombas, maternidades e currais elevados para salvar o gado. Utilizando-se de rápidas canoas ou batelões, esses trabalhadores das águas, explorados em sua força de trabalho e sonhos de emancipação social, cortam e transportam canaranas $^{15}$ para alimentar o animal impossibilitado de se locomover. Na vazante, seus corpos ou corpos de búfalos emparelhados a essas embarcações carregam mantimentos para o sustento da criação bovina. Na estiagem, vaqueiros precisam acompanhar o gado desnutrido por longos quilômetros em busca de pastos; o cuidado para não lhe deixar definhar em atoleiros ou diante de animais nocivos, redobra a atenção. São homens que vivem contínuas tragédias, porque cada estação lhe traz os perigos em gerenciar a fúria ou escassez das águas. Apesar dessas adversidades, eles se tornaram aptos para lidar com estes ciclos geoculturais em enfurecidos desequilíbrios por ações desumanizadoras de projetos globais (Mignolo, 2010.

\footnotetext{
${ }^{14}$ César Barreira, em prefácio redigido para o livro de Fraxe (2000), faz importante afirmação para mostrar como o pensamento colonial lê populações locais, cujas vidas estão cicatrizadas pelo tempo das águas. Assinalou: "Se os homens anfíbios estão perfeitamente equilibrados e harmônicos no ecossistema amazônico (aquático e terrestre), eles aparecem como se estivessem 'fora d'água' na lógica e na racionalidade capitalista".

${ }^{15}$ Espécie de capim utilizado para alimentar o gado, geralmente recostado e encontrado à margem dos rios.
} 


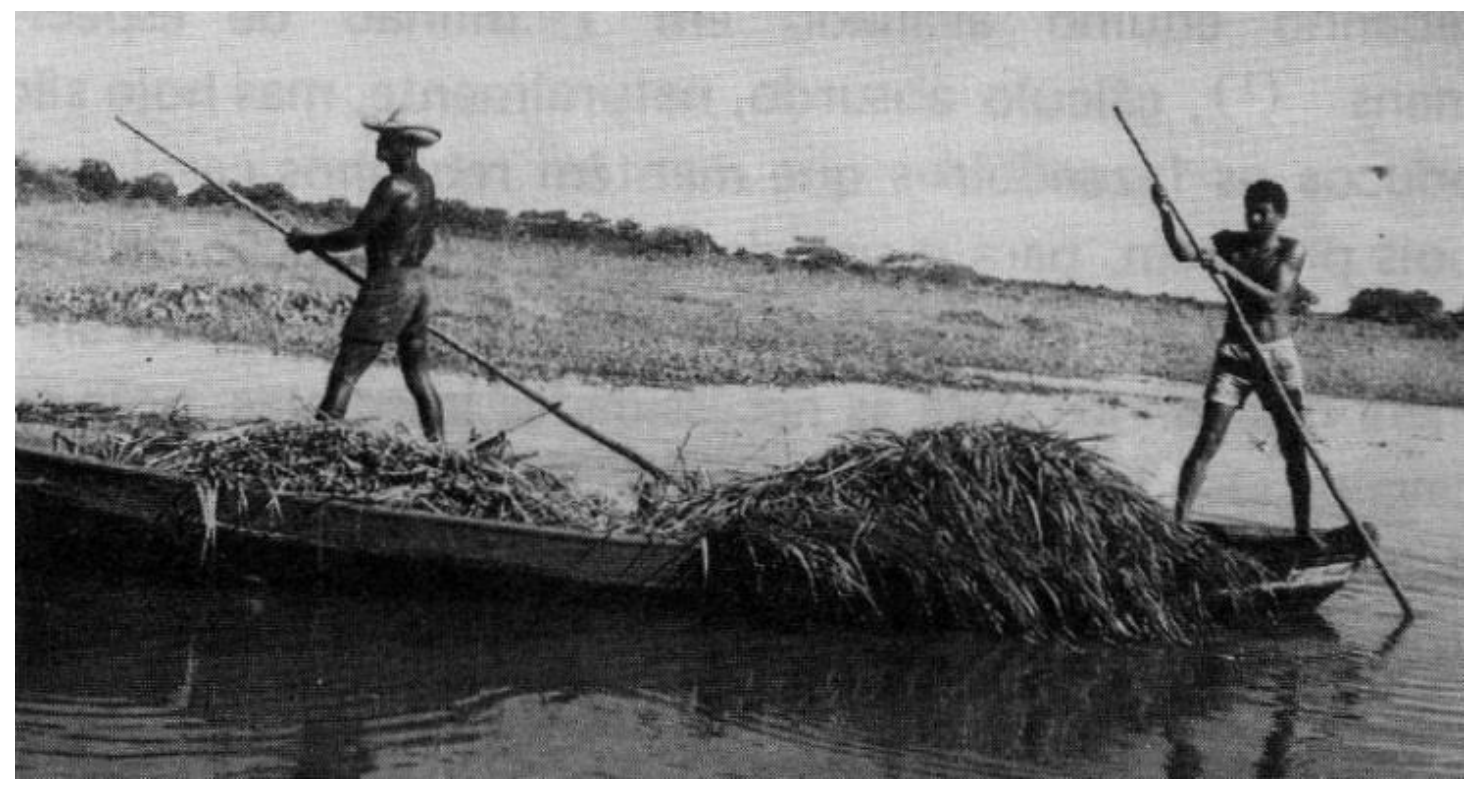

Foto 6. Corpos de negros e afroindígenas de vaqueiros transportando canaranas para alimentar o gado na invernada marajoara. Luxardo (1977, p. 74) os visualiza como marujos em montaria, desafiando a força das águas. Nesse período, as canoas também conduzem os bezerros para lugares mais secos por não resistirem a uma vida em marombas.

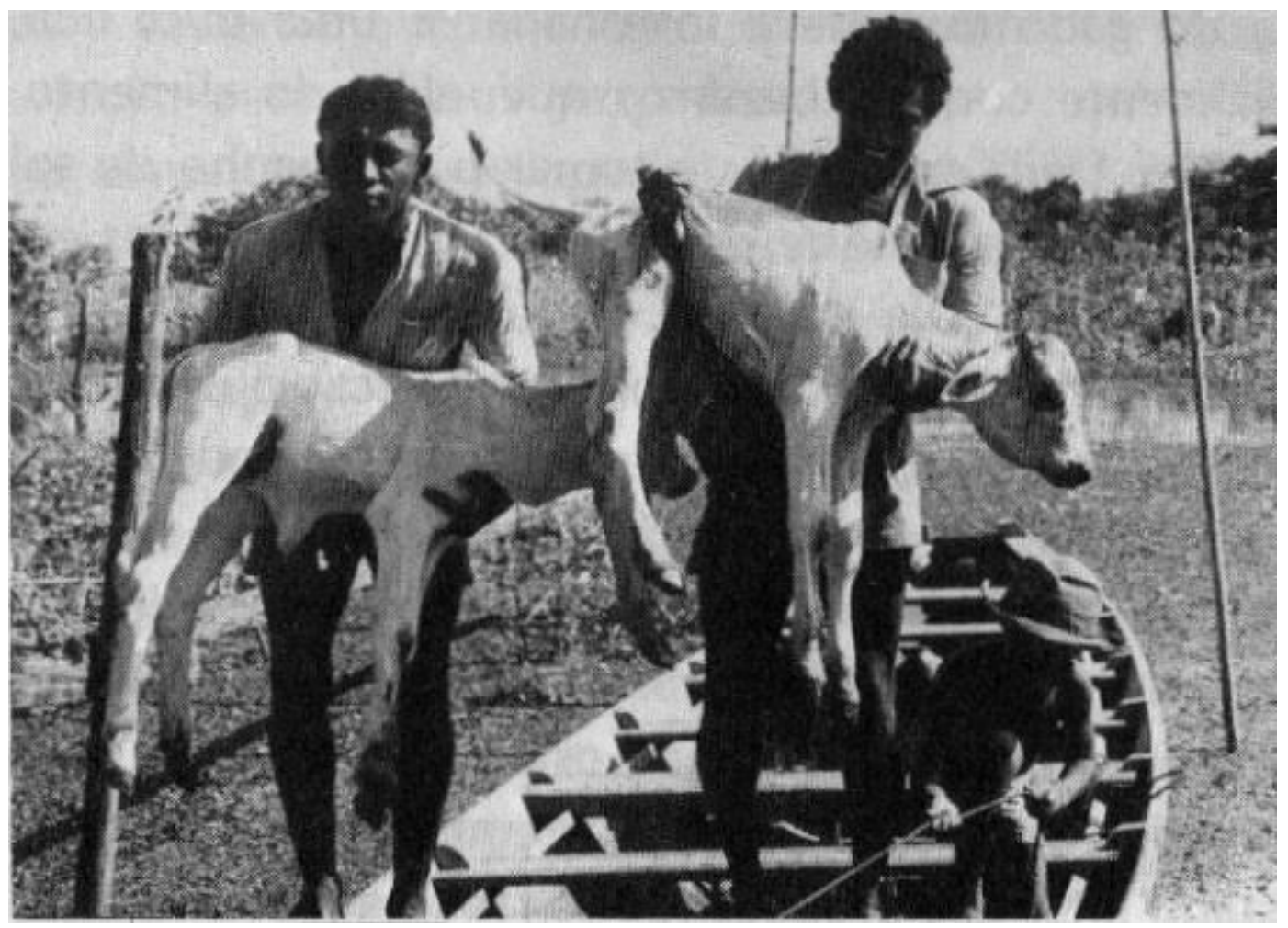

Foto 7. Quando a água cresce, negros vaqueiros precisam salvar os bezerros, dando-lhes atenções especiais. De acordo com Luxardo, graças à destreza, paciência e dedicação desses trabalhadores, os novilhos conseguem ultrapassar a invernada marajoara. (Luxardo, 1972:72). 
A necessidade de chegar até a beira do rio para beber água, coloca o gado nos atoleiros. As reses mais robustas, geralmente, ficam debilitadas e sucumbem. A extensão das fazendas, muitas vezes, não permite ao vaqueiro chegar a tempo de socorrê-las. Entre as décadas de 1930 a 1980, completavam a mutilação de alguns desses animais não somente o imenso esforço realizado para livrarem-se de perigos, como a presença de piranhas e jacarés que, em surdina, a tornavam presas fáceis de sua alimentação.

A presença do rio-mar regendo a vida nos campos abriu as portas da região à criação do búfalo. D. Antônio de Almeida Lustosa, arcebispo de Belém (1931-1941), ao percorrer campos e florestas, entre os anos de 1932 a 1938, escreveu que "de quando em quando, se vê um rebanho de búfalos, deitados à margem do rio, mergulhados na água até o pescoço, a comer canarana de que são ávidos, ou simplesmente a remoer" (Lustosa, 1976:354). A cultura bubalina, introduzida na região nas primeiras décadas do século XIX, mais um século e meio depois das primeiras cabeças de gado vacum vindas do Cabo Verde, em 1644, adaptou-se facilmente ao clima da região marajoara. Enquanto no período seco o bovino emagrece porque os pastos secam, o búfalo anda sempre bem nutrido. O diálogo promovido por D. Antônio com vaqueiros "entendidos do riscado", sobre o criatório dessa espécie na região, fez perceber vantagens e desvantagens.

Animal colossal para tração, o búfalo tem força brutal. As vacas búfalas, mesmo sem tratamento, produzem uma quantidade enorme de leite. Como estão sempre a se alimentar de tudo, seja inverno ou verão, é animal de peso respeitável, “de modo que para carnear é de grande vantagem comercial" (Lustosa, 1976:359). Enquanto o gado sucumbe geralmente nos atoleiros, o búfalo, por ser robusto, sempre consegue sair dos "tremendais". Sem enterrar as mãos nesses atoleiros, liberta-se com maior facilidade. A sabedoria do vaqueiro revela que "a onça, tão terrível quando se atira sobre uma rês, não se atreve a atacar um búfalo, pois ele a persegue sem temor". Piranhas e jacarés que atacam o gado, receiam o búfalo, "parece que não lhes apetece a carne bufalina".

Semelhante a narrativas de D. Antônio de onde se captam competências e habilidades de vaqueiros marajoaras no trato do gado, da pesquisa realizada por Monteiro Baena, nas primeiras décadas do século XIX, apreende-se saberes de pesca, desenvolvidos por populações indígenas, garantidores de seu sustento, como das elites para quem trabalhavam nos pesqueiros. Prática ainda hoje existente em alguns espaços marajoaras, como é visível na capa do livro da $2^{\mathrm{a}}$ edição de "Marajó: A Ditatura das Águas", de Giovanni Gallo (Foto 8). Para Baena os índios aruãs eram mestres na "arte 
piscatória”. Conhecendo o tempo para a captura das espécies, sabiam o tipo apropriado de instrumentos a serem utilizados em cada situação de pesca. Algumas vezes, na boca de seus uatapus atroadores, faziam com que "os peixes atraídos pelo som destes búzios”, viessem logo “emalhar-se em suas redes lançadas” (Baena, 2004:281).

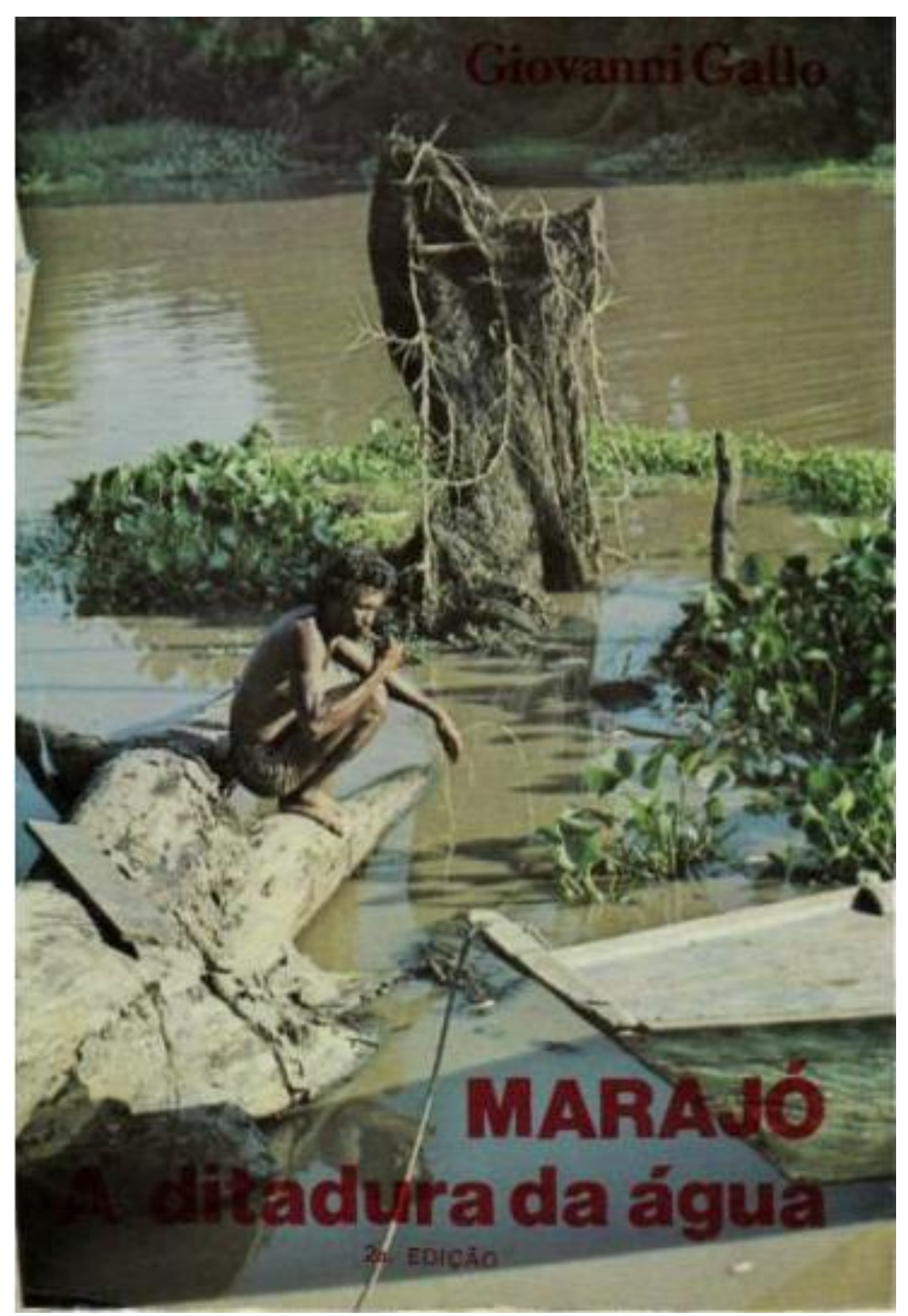

Foto 8. A sugestiva capa da obra de padre Gallo (1980) visibiliza um tempo de espera. O pescador de traços multiétnicos, acocado em tronco de árvore abatida, pacientemente parece usar instrumento sonoro para atrair o pescado à sua rede. A canoa amarrada é sinal de que o tempo de voltar para casa depende da captura do peixe que vem pela reponta da maré - quando as águas se prepararam para crescer. 


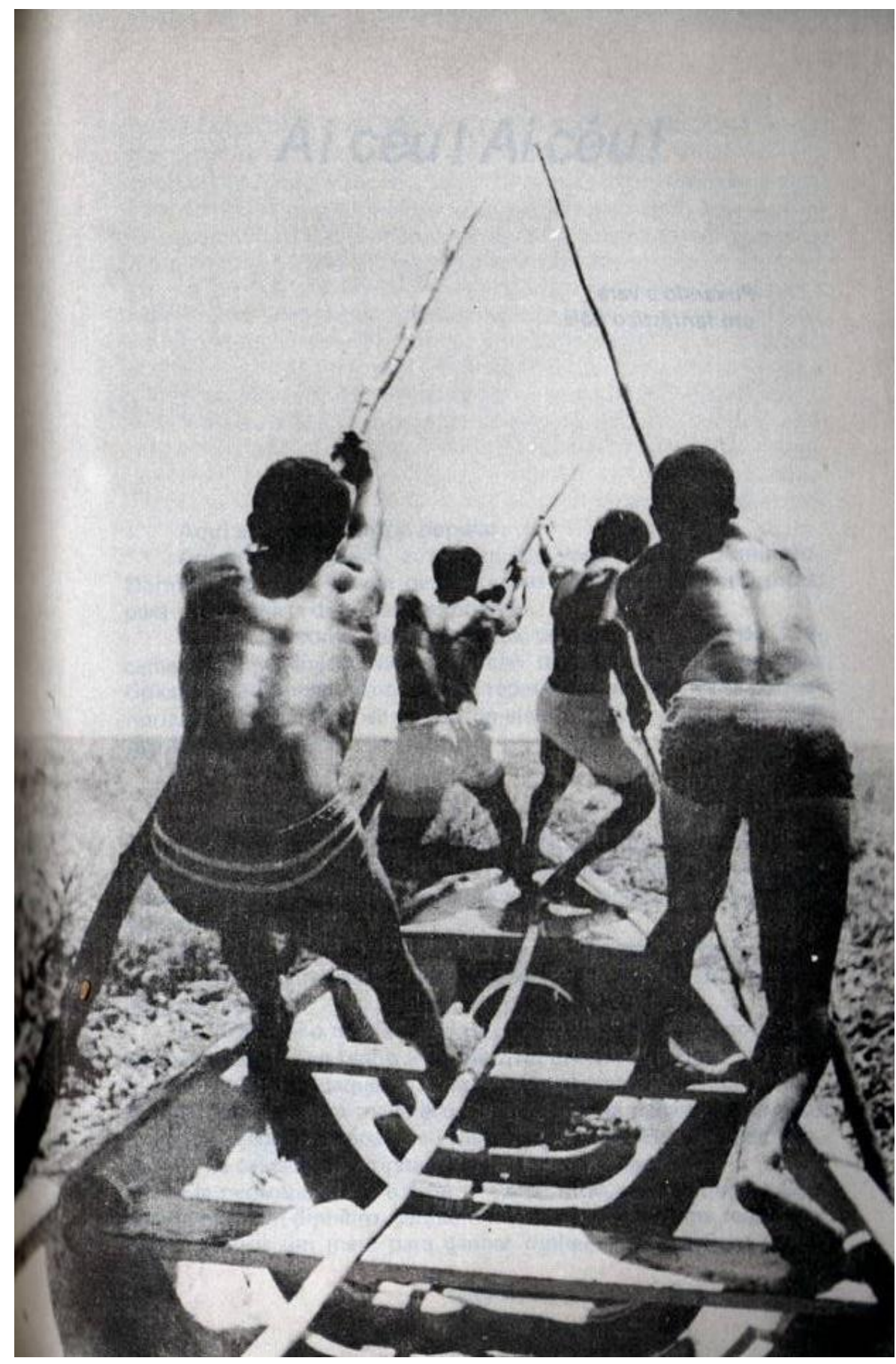

Foto 9. Corpos marajoaras de matrizes étnicas afroindígenas sincronicamente empenhados a vencer a fúria do rio-mar, objetivando atravessá-lo para alcançar paragens longínquas no tempo da pesca. Gallo (1980:157) leu a imagem de homens puxando a vara como um fantástico balé que se dança no ritmo da natureza.

Em sua estada nos campos marajoaras, impressionou D. Antônio a destreza com que, desde pequenos, filhos de ameríndios e negros aprendem a domar o gado em laços. Antes, "lançam o galho da árvore, lançam as galinhas, as cabras, os bezerros, lançam-se mutuamente, e é tudo um exercício continuado para adestrar os admiráveis lançadores 
que nos assombram com a sua perícia" (Lustosa, 1976:344). O saber-fazer dos vaqueiros se expressa nas lançadas seguras quando disparam pelos campos a cavalos domados e inteligentes, atracando chifres curtos, no seu preciso golpe de vista, deixando ver coragem, previsão e conhecimento dos instintos do gado ${ }^{16}$. Esse conjunto de habilidades fez o arcebispo pensar na longa formação pela qual passa a criança do Marajó dos Campos, para aprender a prática de convivência com a cultura do gado.

No surdo e incessante movimento construtivo dos rios, populações locais perpetuaram técnicas e instrumentos de pesca artesanais extremamente inteligentes. Arcos, flechas, anzóis, zagaias, iscas como minhocas, insetos, frutas, assim como paris ${ }^{17}$, cacuris $^{18}$, tapagens de talas de bambus ${ }^{19}$, ramas verdes e troncos, $\operatorname{covos}^{20}$, rupichéis, redes e puçás ${ }^{21}$ compõem parte do conjunto de artefatos de uma cultura material herdada de povos ancestrais, nativos ou diaspóricos à região, sensivelmente sintonizados a temporalidades das águas. Nunes Pereira (1956:69) assinalou que, quando estes elementos lhes faltavam, "recorriam a plantas íctio-tóxicas ${ }^{22}$ para tinguijar as águas e matar os peixes de superfície e de profundidade".

No tempo das secas, não somente a paisagem do Marajó dos Campos modificase como também os canoeiros desenvolvem outras práticas de trabalho e vivência. Uma delas é o modo de viajar a espia, semelhante à foto abaixo. Em vez de o ribeirinho ser conduzido pela canoa, em virtude da ausência de vento e maré baixa, este, caminhando a pé pelas margens despidas de matas e com uma corda comprida amarrada à canoa pela outra extremidade, reboca a embarcação. D. Antônio de Almeida Lustosa observou a dificuldade do ribeirinho de remar, porque os rios não apresentam, nesse tempo, margens sólidas e limpas. Para resolver suas necessidades de deslocamento, operam com o método de arrastar a pesada canoa dentro d'água. Ficou impressionado com esta cena porque "volumosa no seu bojo, com seus mastros e respectiva cordoalha, com a grande vela, em

\footnotetext{
${ }^{16}$ A relação entre antropologia e aprendizagem tem ganhado espaço nos últimos anos. Ver, por exemplo, Horizontes Antropológicos, com a temática Cultura e Aprendizagem, Porto Alegre, ano 21, n. 44, jul./dez. 2015.

${ }^{17}$ Esteira produzida de talas para tapar boca de igarapés, objetivando, no tempo da maré baixa, capturar o peixe.

${ }^{18}$ Ver nota 22 deste capítulo.

${ }^{19}$ Semelhante a paris.

${ }^{20}$ Instrumento confeccionado de talas, em formato oval, para captura do camarão.

${ }^{21}$ Semelhante a covos.

${ }^{22}$ Esta raiz possui espécie de veneno para abater o pescado, também conhecida como timbó, hoje proibida por leis ambientais. Geralmente, na vazante da maré, o pescador fechava a boca e a saída do igarapé com paris e batia a raiz na água. Com alguns minutos depois, o peixe em desespero começava a flutuar, facilitando sua captura.
} 
geral colhida, a embarcação parece não poderia ser rebocada senão por algum elefante, como se usava outrora na Índia. Entretanto, um homenzinho a desloca sem grandes esforços" (Lustosa, 1976:349).

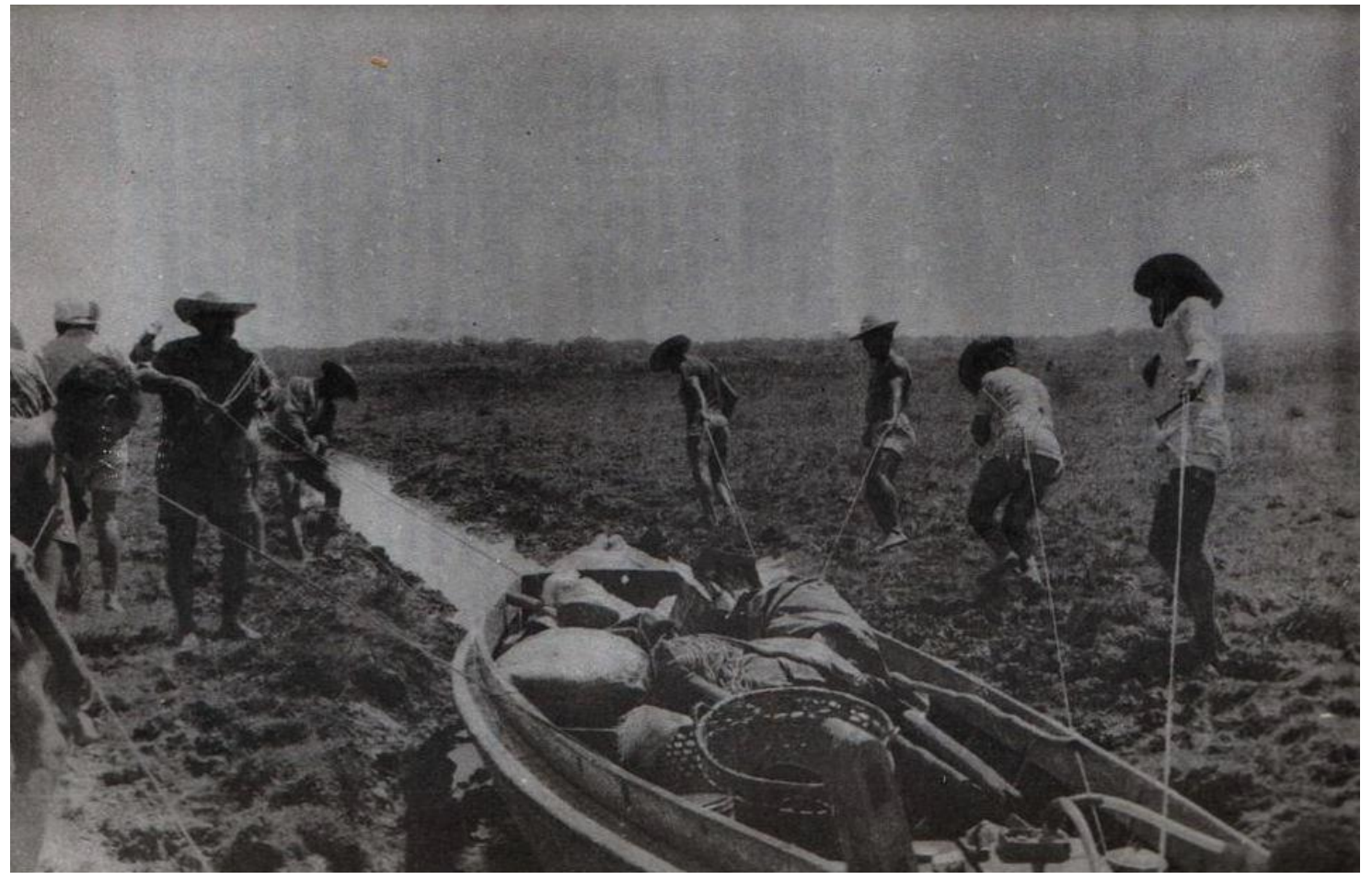

Foto 10. Corpo a corpo homens e embarcação motorizada. Em vez de a canoa levá-los, são eles que a conduzem, puxando-a por finos, mas resistentes cabos. Objetos pessoais, instrumentos da cultura material de pescadores e caçadores recebem proteção. A leitura de Giovanni Gallo (1980:231) assinala homens

"puxando o casco na espia", semelhantes a gentes "de um passado tenebroso, como bichos".

O rio Arari, na década de 1930, era ladeado de campos aproveitáveis à pecuária. Suas águas movimentadas por embarcações expressavam marcas de uma vida sob o regime das águas com formas de trabalhar e comercializar, próprias a espaços flutuantes. Canoas conduzidas por filhos de indígenas, negros e afroindígenas levavam o gado ${ }^{23}$, abastecendo cidades vizinhas e a capital do Estado; outros canoeiros carregavam o gelo para a pesca em alto mar. Havia aqueles que partiam com carregamento de peixe salgado, além dos persistentes regatões, que tanto perturbaram a ordem econômica e política ao longo dos séculos XVIII e XIX. A visão de um viajante da foz até o lago Arari, escreveu

\footnotetext{
${ }^{23}$ Segundo Dom Antônio Lustosa (1976), havia na década de 1930 fazendas, na zona do Arari, que contavam com trinta, quarenta e cinquenta mil reses nos seus campos.
} 
D. Antônio, se preenche com belas vivendas, intermináveis campos de criatório de gado, caiçaras $^{24}$, rebanhos numerosos de bois e manadas de búfalos, taperaís de pescadores ${ }^{25}$.

A convivência com a dinâmica da natureza, regidas pelas cheias, - tempo de cabeça-d'água, também conhecida de lançante pelos ribeirinhos da região, - como secas, tempo de tepacuema, fez as visitas pastorais de D. Antônio serem conduzidas por diferentes embarcações ou outros meios de locomoção, como o cavalo ou a carroça puxada por cavalos ou bois. Havia localidades com fazendas à margem do rio onde o porto ficava raso $^{26}$. Para alcançar esses lugares, o arcebispo e seus ajudantes deixaram a canoa Ondina e pularam para a Nimpha, de menor calado. Na vasta arena líquida que envolve Bagre, Oeiras e Curralinho, no Marajó das Florestas, os canoeiros de ontem e de hoje continuam a perlustrar ${ }^{27}$ em frágeis embarcações, vivendo constantes riscos e perigos, mesmo que, no presente, a tecnologia tenha possibilitado a construção de transportes fluviais mais seguros.

Nos anos de 1936, no percurso de Oeiras para Curralinho, o arcebispo de Belém conheceu um menino ribeirinho de 13 e 14 anos, o qual, na véspera, fez o caminho inverso, em uma pequena embarcação. O cotidiano do adolescente era ajudar o pai a atravessar pessoas e mercadorias no pequeno transporte. O caminho percorrido anteriormente foi para transbordar um moço a Oeiras. O tempo não estava tempestuoso, mas ventava muito, encrespou as ondas e os dois se alagaram. A "valência" foi ser o barco de madeira leve, que mesmo cheio de água, continuou a flutuar. Segundo o arcebispo, nem o menino tripulante e nem o moço viajante "perderam o sangue-frio".

Nadando no rio, apoiados na canoa alagada, tripulante e viajante com uma mão desalagaram a embarcação e seguiram viagem. No dia seguinte, o menino "sem a maior apreensão" pegou carona, amarrando seu casco na lancha da visita pastoral. Impressionado por aquelas artes da vida sobre águas, o religioso encerrou a narrativa contando que, antes de chegar a Curralinho, o pequeno tripulante desamarrou a corda presa à lancha e seguiu seu destino na maior naturalidade, fazendo-se "novamente joguete daquelas ondas irrequietas".

\footnotetext{
${ }^{24}$ Embarcadouros de gado que consistem em currais com saídas afuniladas, pelas quais as reses são encaminhadas às lanchas. Idem, p. 351.

${ }^{25}$ Provisórias habitações abandonadas por pescadores, situadas à margem de rios, no período de reprodução do peixe.

${ }^{26}$ Estas fazendas eram Paraíso, São João, São Joaquim, São Joaquinzinho, Arari, São Pedro, Tuiuiú, Menino Deus, Flor de Inajá, Jenipapo.

${ }^{27}$ Percorrer, singrar, viajar.
} 
Estas narrativas compostas pelo prelado permitem acompanhar um universo de gentes e suas habilidades em lidar com o regime das diferentes correntes marítimas que deságuam entre campos e florestas. Saberes de pesca, coletas de frutos do rio ${ }^{28}$, seu poder curativo, práticas de trabalho como as realizadas por mulheres coletoras de açaí, de traços afroindígenas, habitantes de Muaná, são tarefas registradas por D. Antônio e, ainda hoje, desenvolvidas por populações da floresta marajoara.

As mulheres descritas por D. Antônio aparecem com grandes cestos presos em suas costas pendentes por uma faixa que lhes cingia a testa e as faziam sentir todo o peso da carga depositada no utensílio. Costume próprio de uma região fortemente marcada por hábitos de trabalhar desenvolvidos por populações indígenas e africanas. Tal prática retoma a divisão social e tradicional das tarefas: ao homem competia levar o arco e a flecha e às mulheres o aturá, a carga.

Na década de 1990, outro religioso que alcançou os Marajós, Frei Cleto Millán, deixou-se influenciar profundamente pelo tempo marajoara. Este reverendo, cuja trajetória, entre outros aspectos, seria marcada por um forte combate à expansão do protestantismo em Afuá e nos municípios sob sua responsabilidade pastoral (Chaves e parte de Anajás e algumas localidades do município de Breves), fez uma opção consciente e pública para viver sua missão em terras marajoaras. Em seu primeiro ano de pároco, já impressionado e influenciado pela dinâmica de rios, marés e ventos, com grande sensibilidade compôs um retrato da região:

\begin{abstract}
Afuá tem um jeito especial: aqui o mato, a água e o céu cantam juntos uma inefável sinfonia. Aqui é muito importante a virtude da esperança. Navegamos esperando que tudo dê certo. Olhamos para o céu para ver se a chuva está chegando ou quando vai parar. Olhamos para os rios esperando quando a maré vai ser a favor. Olhamos para a baia esperando que a maresia termine e que a pororoca não se apresente, não. Olhamos para o salão paroquial esperando que o povo chegue com pontualidade. Nós aqui esperamos... Esperar aqui é muito importante (Garcia, 2000:67).
\end{abstract}

\footnotetext{
${ }^{28}$ A ucuuba e a andiroba são duas destas sementes coletadas nos rios. A primeira, conhecida na Guiana Francesa como árvore do sebo, produz um óleo espesso que se solidifica e toma o nome de sebo. Usava-se para fabrico de sabão e velas. Conforme D. Antônio, quando o "caboclo" queria improvisar uma vela, tomava uma vara ou tala muito fina e nela enfiava várias frutinhas secas de ucuuba: estava pronta a vela, era só acender. Ardia com boa luz até consumir-se a última frutinha. Além desta função, azeites produzidos por essas sementes são muito utilizados para puxações e afomentações em áreas doloridas do corpo. Ucuuba e pracuuba (Lustosa, 1976: 379). A amarga andiroba serve também para fazer sabão, sendo um produto lubrificante que produz iluminação. Nesse campo, destaca-se ainda o patauá, do qual o ribeirinho extrai o azeite fino, bastante utilizado como comestível e com mil outras aplicações industriais. Com uma prensa retirava o azeite vendido para regatões que alcançavam diferentes cidades. Junto ao açaí e a bacaba, o patauá, fruto de caroço maior, no seu tempo de safra, produz o vinho que alimenta geralmente as populações rurais, quando termina a safra do açaí. (Lustosa, 1976: 362).
} 
Nesse universo singular, perenizado por habitantes de culturas dos sentidos, outras cosmogonias, ritmos de vida, compreensões de mundo tornam-se visíveis e vivenciados em impressões escritas e convivências pessoais. Seus saberes, fazeres e crenças trazem sempre, implícito ou explicitamente, marcas da presença de lugares pantanosos e flutuantes. Esses territórios, onde se surpreendem valorizações de expressões sensíveis e afetivas alinhavadas por populares insulares em seu meio ambiente, não podem ser tomados como "isolados e homogêneos, isentos de conflitos" (1997:8). Nos municípios marajoaras significativa parcela dos moradores, apesar de dispersa em rios, furos e igarapés, continua reunindo-se para trabalhar, festejar, celebrar, reafirmando sociabilidades de seus modos de viver, pensar, trabalhar e estar no arquipélago.

Jerusa Pires Ferreira em Memórias das Águas, assinalou que, "na Amazônia, a água é presença e movimento, é a própria organização das paisagens culturais e humanas, anímica e definidora, a água é o bordão da memória" (Ferreira, 2004:13). A compreensão de Ferreira ajuda perceber, em semelhança ao pensamento de Victor Leonardi (1999), não ser possível compor histórias de povos e culturas gestados ou habitados em ambientes amazônicos sem vislumbrar a pujante força gerenciadora do "líquido sagrado" na constituição de identidades, saberes e religiosidades locais.

Nessas terras insulares, arrimos de variadas memórias, congregaram-se histórias reais e fantásticas, forjadas por imaginários de culturas orais, fluviais e florestais. Leandro Tocantins, em livro intitulado, $O$ rio comanda a vida, recupera uma narrativa fantástica, popularizada entre viajantes que desciam, em navios gaiolas e transatlânticos pelos Estreitos de Breves ${ }^{29}$, ao longo dos séculos XIX e XX, especialmente, no soturno furo Aturiá, na volta do Vira-Saia, fronteira com o município de Melgaço. Segundo este estudioso, os habitantes desse pedaço do arquipélago costumavam dedicar às divindades autóctones, todo sortimento de roupas e trapos jogados por viajantes quando por ali passavam. A origem da "estranha oferenda" assenta-se numa narrativa repleta de códigos

\footnotetext{
${ }^{29}$ Os estreitos de Breves, válvula de escape para a navegação amazônica fugir do temido cabo Maguari, na parte externa da ilha, posta em contato com o oceano, possuem canais caudalosos que se tornaram rotas obrigatórias de canoas a remo, à vela, navios gaiolas, transatlânticos, barcos motorizados, navios de linha, permitindo a povos e culturas viajarem em diferentes tempos e direções. Quem olha por cima da floresta a esse estreito, tem a impressão de que as embarcações estão afogadas na floresta, em função da reduzida largura da avenida fluvial e a imponência da flora. Leandro Tocantins (1988) acredita que, no ano 3000, a ilha, antigamente partida, será novamente soldada em suas partes desgarradas, transformando-se numa península.
} 
de povos de tradições orais, culturalmente moldados e sintonizados com correntes e seres das águas marajoaras. De acordo com Tocantins (1988:29-30):

\begin{abstract}
Uma canoa subia o furo nos primitivos tempos da conquista, e ao dobrar a volta do Vira-Saia surgiram pela proa centenas de botos, fungando e ameaçando a pequena embarcação, que ficou paralisada, sem poder prosseguir a derrota ou retroceder. Repentinamente, um coro de vozes se fez ouvir, entoado por jovens desnudas que afloravam das águas. As lindas iaras pediam roupas para cobrir o corpo, e tão logo as peças eram jogadas pelos caboclos atemorizados as visões desapareceram, e a canoa pôde continuar a viagem.
\end{abstract}

No século XIX, o viajante e naturalista Henry Walter Bates, assinala Tocantins, também registrou entre "caboclos tripulantes do barco em que viajava", a referida narrativa. Apesar de trazer outros elementos, conservou o imaginário da oferenda como "superstição" criada pelas populações locais para manterem-se em sintonias com entidades dos rios. $\mathrm{Na}$ atualidade, essa prática ganha outros usos e apropriações.

Quando minha família habitava o espaço rural do município de Breves, eu e meus irmãos ao avistarmos navios e princesas pegávamos nosso casco e ficávamos no meio no rio para pedir que nos jogassem presentes. Era comum ganharmos comida, roupas e brinquedos. Hoje, quando se viaja pelo estreito de Breves ou por outros espaços da região, crianças carentes, geralmente acompanhadas de suas mães, procuram seguir a embarcação para pedir ajuda em dinheiro, roupas e alimentação.

O sistema geocultural da região deixa ver em suas esteticidade que para se construir casas, vilas, cidades, espaços públicos e sagrados é preciso conhecer e compreender a constituição física e a dinâmica de seus múltiplos e diferentes ecossistemas.

É somente desta maneira que se pode saber o tipo de material apropriado ao ambiente, pois do contrário, enfrentar-se-á sérios problemas com sua manutenção, especialmente em tempos de enchentes, quando determinados insetos sobem em busca de novos habitats. As características físicas do terreno de várzea onde nasceu a cidade de Afuá, por exemplo, originaram um núcleo urbano muito sui generis, destacando-se, no panorama das urbanidades marajoaras, por ser toda construída em cima de pontes, o que lhe rendeu o título de A Veneza do Marajó, única cidade a possuir leis municipais proibindo o tráfego de carros e motos em seu perímetro citadino.

Por esses traçados físicos, durante mais de 60 anos, os padres espanhóis que assumiram a direção da Paróquia de N. Sra da Conceição em Afuá debateram-se para 
vencer a presença malfadada do "cupim branco da terra, que devorava tudo em pouco tempo, sem fazer alarme, pois trabalhando por dentro dos esteios, corroia os empalmes do vigamento" (Legarda, 1961:50) A ação "maldita" dessa espécie de cupim só foi debelada nos primeiros anos do século XXI, quando a matriz de N. Sra da Conceição deixou de ser em madeira e passou a cimento.

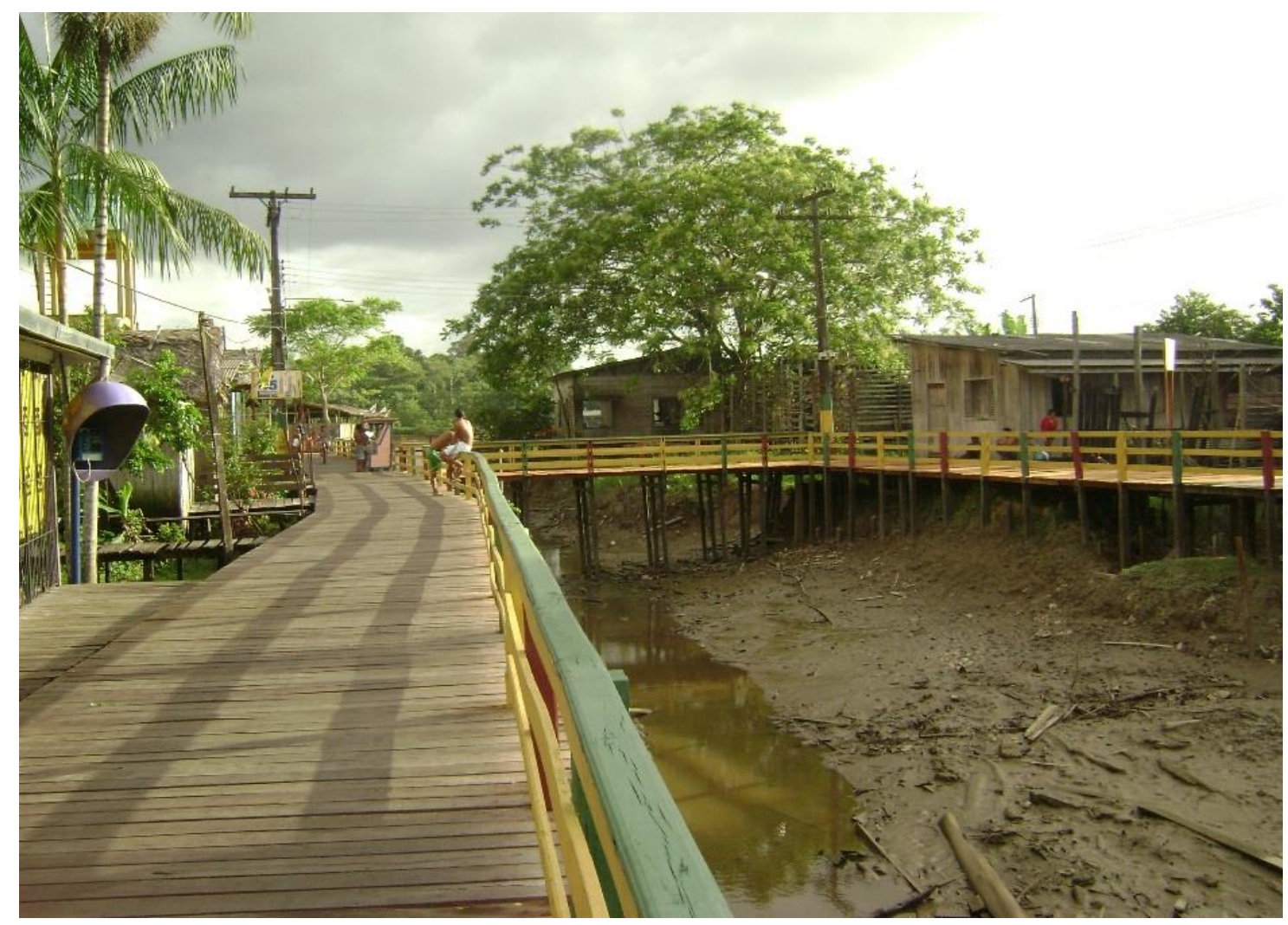

Foto 11. Vista de ruas de Afuá. Na imagem, orelhão telefônico, rede de energia elétrica, banca de venda de bombons, pessoas conversando, comungam espaços com expostos lamaçais em tempo de maré baixa. Pesquisa de Campo, agosto de 2008. 


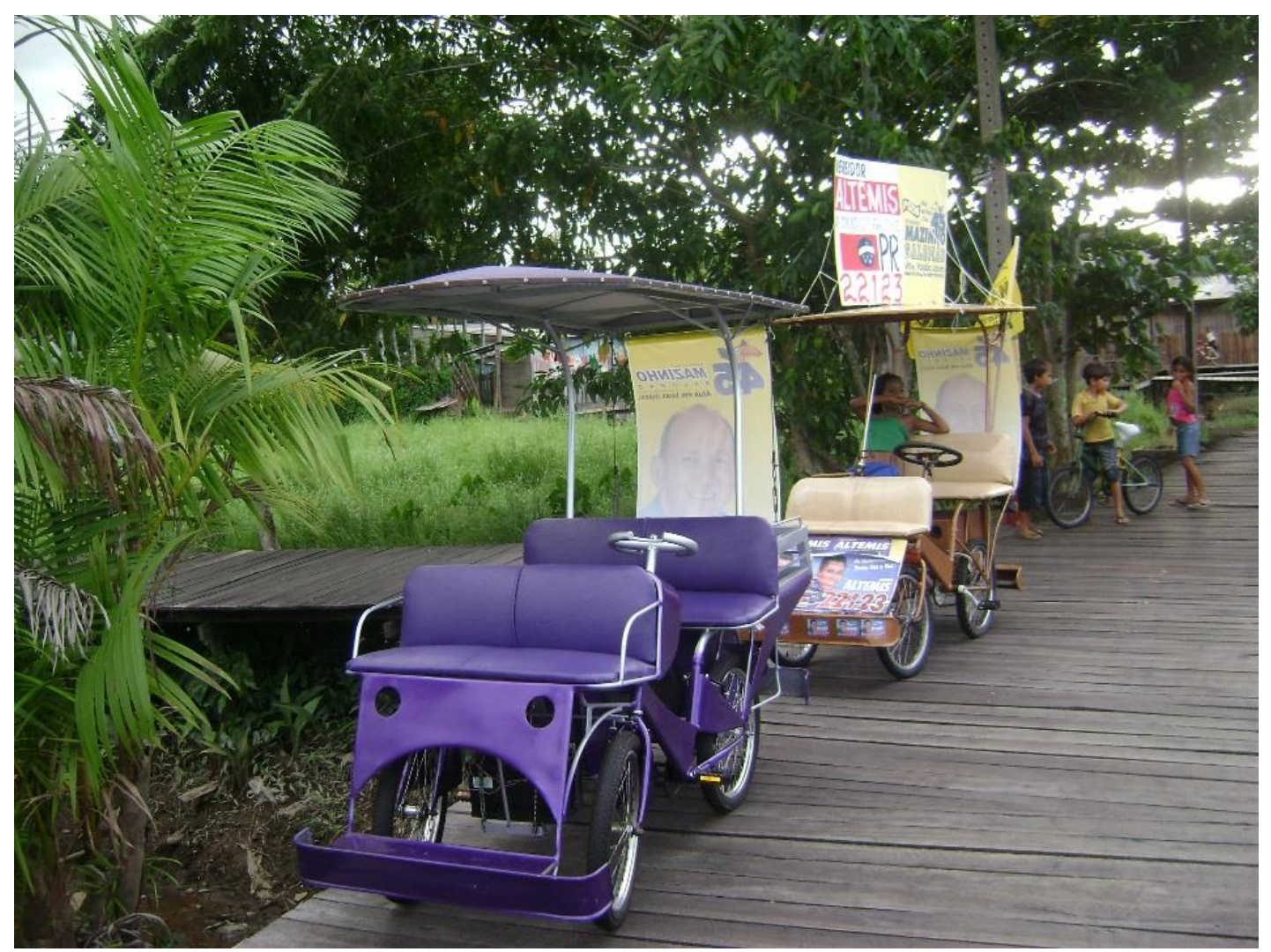

Foto 12. Bicitáxi afuaense, arte criativa em rodas revela a perspicácia do marajoara para adaptar-se a necessidades e singularidades de um espaço urbano, protegido por leis municipais que não autorizam o uso de meios de transportes mais pesados na extensão da cidade-floresta. Em época de campanha eleitoral, esses meios de transporte, acompanhados de caixas auto-falantes, são responsáveis por propalar músicas e planos políticos de candidatos a cargos eletivos na gestão municipal, assim como são padronizados e utilizados pela gestão pública e empresas particulares para prestar serviços em Afuá. Arquivo da Pesquisa, agosto de 2008.

\section{Deixando as Águas: Últimas Palavras}

Ouvir o outro, os outros, é ampliar a dimensão espiritual de sua própria língua, ou seja, colocá-la em relação. Compreender o outro, os outros, é aceitar que a verdade de outro lugar se justaponha à verdade daqui. E harmonizar-se ao outro, é aceitar acrescentar às estratégias particulares de cada língua regional ou nacional, estratégias de conjunto que seriam discutidas em comum (Glissant, 2005:54-55).

As paisagens marajoaras com seu poderoso regime das águas gestam relações de extrema dependência homem, mulher e meio ambiente, reveladas em sociedades, cidades, vilas ou casas flutuantes ali configuradas. A água é a grande metáfora da vida, pois dela, nela ou por ela emanam, correm e podem ser concretizadas todas as necessidades humanas, intelectuais, espirituais de que habita em ínsula. Somente populações inseridas num sistema de símbolos e crenças são capazes de assegurar suas específicas formas de vida e criar explicações para a existência de encantados, visagens, assombrações e seres 
míticos, tão fortemente desclassificados pela lógica ocidental cartesiana e iluminista como folclore, superstição e ignorância. Para essa ciência abissal, no mundo das populações tradicionais "não há conhecimento real; existem crenças, opiniões, magia, idolatria, entendimentos intuitivos ou subjetivos, que na melhor das hipóteses podem se tornar objeto ou matéria-prima de investigações científicas" (Santos, 2007:72). Na contramão da razão colonizadora, populações marajoaras interpretaram e traduziram os códigos culturais em fronteiras, realizando uma espécie de "ecologia de saberes" na esteira do que advoga Boaventura Santos, para mostrar habilidade em articular saberes locais e saberes globais sem hierarquia e exclusão.

Assim, poderia dizer que as fotografias em sua autoridade etnográfica (Clifford, 2011) e autonomia textual se apresentaram neste artigo "como uma outra forma de narrativa" (Achutti, 1997:64) capaz de ampliar, enriquecer, aprofundar ou produzir outras leituras da realidade e do sistema cultural que se deseja compreender, numa perspectiva decolonial, porque questiona "padrões de poder em suas dimensões materiais e subjetivas, da existência social cotidiana e da escala social" (Quijano, 2000:342).

Aspecto importante nesse campo está na diferença e semelhança que historiadores e antropólogos deixam perceber no uso das imagens em suas pesquisas. Ultrapassando a ideia limitada de que o historiador só trabalha com imagens antigas e o antropólogo com imagens capturadas no presente etnográfico, Darbon (1998, p. 103) lembra que qualquer pesquisador tem a liberdade de explorar, em "quadro de suas pesquisas", não apenas “documentos que ele mesmo produz por ocasião de sua presença no campo: pode também aplicar-se à análise das imagens produzidas por outros".

Assim, nos enredos das narrativas de cronistas, viajantes, literatos, historiadores, antropólogos, entre outros escritores dos séculos XIX e XXI, e no relato imagético de fotografias produzidas durante a pesquisa de campo realizada em 2008 ou no raio das décadas de 1950 a 1980 pelo etnólogo Manuel Nunes Pereira, cineasta Líbero Luxardo e padre Giovanni Gallo, esforcei-me para reconfigurar como se produz e se reproduz a vida na Amazônia Marajoara, procurando explicitar saberes e aprendizagens, assim como dificuldades e especificidades para se viver e compreender dinâmicas da existência no Marajó. Cruzar narrativas verbais e visuais, numa sociedade plena de tradições de oralidade, em que as letras tiveram lugar secundário na constituição das formas culturais, questiona representações de colonialidade do poder, do ser e do saber, formuladas por percepções estrangeiras, nacionais ou mesmo regionais sobre as populações marajoaras 
(Quijano, 2000; Mignolo, 2003; Landes, 2005). Moriz Schwarcz assimila essas construções como olhares inviesados, cujos reflexos não visibilizam apenas a cultura alheia, mas em efeito bumerangue "alteram e diferenciam seu próprio mundo, tornandose estranho a si próprio, questionando referentes, normas e padrões culturais. O estranhamento da viagem e das imagens fotográficas não é, assim, relativo apenas ao “outro", mas sempre ao próprio viajante, fotógrafo ou estrangeiro, que se dá conta da própria relação de alteridade" (Schwarcz, 2001:616).

\section{Referências}

ACHUTTI, Luiz Eduardo Robinson. Fotoetnografia: um estudo de antropologia visual sobre cotidiano, lixo e trabalho. Porto Alegre: Tomo Editorial: Palmarinca, 1997.

ANTONACCI, Maria Antonieta. África/Brasil: corpos, tempos e histórias silenciadas. Revista Eletrônica Tempo \& Argumento, $\mathrm{n}^{\circ}$ 1, Florianópolis, UDESC, p. 46-67, maio, 2009.

ARAÚJO, Lucas Monteiro de. Representações Marajoaras em Relatos de Viajantes: Natureza, Etnicidade e Modos de Vida no Século XIX. Dissertação (Mestrado em Antropologia), UFPA, Belém, Pará, 2017

BAENA, Antônio Ladislau Monteiro (1782-1850). Ensaio corográfico sobre a Província do Pará. Vol. 30. Brasília: Senado Federal, Conselho Editorial, 2004.

BASTIDE, Roger. As Américas negras. São Paulo: EdUSP, 1974 [1967].

BERND, Zilá e LOPES, Cícero Galeno (org.). Identidade e estéticas compósitas. Canoas: Universitário La Salle/ Porto Alegre: PPP - Letras UFRGS, 1999.

BHABHA, Homi K. O local da cultura. Tradução de Myriam Ávila, Eliana Lourenço de Lima Reis e Gláucia Renate Gonçalves. Belo Horizonte: Editora UFMG, 2003.

BONI, Paulo César e MORESCHI, Bruna Maria. Fotoetnografia: a importância da fotografia para o resgate etnográfico. Doc On-line, n.03, p. 137-157, dezembro 2007.

CAMPOS, Ricardo. A cultura visual e o olhar antropológico. Visualidades. Goiânia, v. 10, n.1, p. 17-37, jan-jun. 2012.

CLIFFORD, James. A Experiência Etnográfica: antropologia e literatura no século XX. Organização de José Reginaldo Santos Gonçalves. 4. ed. Editora: UFRJ, 2011.

DARBON, Sébastien, "O Etnólogo e suas Imagens”. In: SAMAIN, Etienne (org.). $O$ Fotográfico. São Paulo: Hucitec, 1998, p.101-111.

DANIEL, João (1722-1776). Tesouro descoberto no máximo rio Amazonas. V.1. Rio de Janeiro: Contraponto, 2004. 
DELEUZE, Gilles e GUATTARI, Félix. Mil Plâtos: capitalismo e esquizofrenia. Vol. 1 e 2. Rio de Janeiro: Ed. 34, 1995.

DIEGUES, Antonio Carlos. As ilhas e arquipélagos tropicais brasileiros: práticas sociais e simbólicas. In: DIEGUES, Antonio Carlos (org.). Ilhas e Sociedades Insulares. São Paulo: NUPAUB, 1997.

FARES, Josebel Akel. Cartografias marajoaras: cultura, oralidade, comunicação. Tese de Doutorado em Comunicação e Semiótica pela PUC-SP. São Paulo, 2003.

FERREIRA, Jerusa Pires. Memória das águas. Asas da Palavra, Belém, Unama, v. 6, n. 18, P. 13-16, dez. 2004.

FIGUEIREDO, Aldrin Moura de. A cidade dos encantados: pajelanças, feitiçarias e religiões afro-brasileiras na Amazônia, 1870-1950. Belém: EdUFPA, 2009.

FIGUEIREDO, Aldrin Moura de. Quem eram os pajés científicos? Trocas simbólicas e confrontos culturais na Amazônia, 1880-1930. In: FONTES, Edilza (org.) Coleção Contando a História do Pará: Diálogos entre Antropologia e História. Belém: E.Motion, 2003, p. 55-86.

FISCHER, Michael. Iran: From Religious Dispute to Revolution. Cambridge, Mass, Harvard University Press, 1980.

FLEURI, R. M. Intercultura e educação. Revista Brasileira de Educação, n. 23, p. 16-35, 2003.

FOUCAULT, Michel. Microfísica do poder. Organização e tradução de Roberto Machado. Rio de Janeiro: Edições Graal, 1979.

FRAXE, Terezinha J. P. Homens Anfíbios - Etnografia de um campesinato das águas. São Paulo: Annablume; Fortaleza: Secretaria da Cultura e do Desporto do Governo do Estado do Ceará, 2000.

GALLO, Giovanni. Marajó: a ditadura da água. 3. ed. Belém/Santa Cruz do Arari: Edições "O Nosso Museu, 1981.

GALLO, Giovanni. Marajó: a ditadura das águas. 2. ed. Belém: SECULT, 1980.

GARCÍA CANCLINI, Néstor. Culturas Híbridas: estratégias para entrar e sair da modernidade. Tradução Heloísa Pezza Cintrão, Ana Regina Lessa. $3^{a}$ edição. São Paulo: Edusp, 2000.

GARCÍA CANCLINI, Néstor. Diferentes, Desiguais e Desconectados: mapas de interculturalidade. Tradução Luiz Sérgio Henrique. $3^{\text {a }}$ ed. Rio de Janeiro: UFRJ, 2009.

GARCIA, Fr. Cleto Millán Garcia. Relatório Anual da Comunidade de Afuá - 1999. In: BPSTV/OAR. Ano LXXX, enero/junio, 2000, num. 550. 
GEERTZ, Clifford. Do ponto de vista dos nativos: a natureza do entendimento antropológico. In: O Saber Local: Novos Ensaios em Antropologia Interpretativa. Tradução de Vera Mello Joscelyne. 8. ed. Petrópolis, RJ: Vozes, 2006, p. 85-107.

GEERTZ, Clifford. Obras e Vidas: o Antropólogo Como Autor. Tradução Vera Ribeiro. 3. ed. Rio de Janeiro: Editora UFRJ, 2005.

GEERTZ, Clifford. Uma Descrição Densa: Por uma Teoria Interpretativa da Cultura. In: A Intepretação das Culturas. Rio de Janeiro: LTC, 2012, p. 03-21.

GILROY, Paul. O Atlântico Negro: modernidade e dupla consciência. Tradução de Cid Kinipel Moreira. São Paulo: Editora 34; Rio de Janeiro: Universidade Cândido Mendes; Centro de Estudos Afro-Asiáticos, 2001.

GLISSANT, Édouard. Introdução a uma poética da diversidade. Tradução de Enilce do Carmo Albergaria Rocha. Juiz de Fora: Editora UFJF, 2005.

GOLDMAN, Marcio. A Relação Afroindígena. Cadernos de Campo, São Paulo, n. 23, 213-222, 2014.

GOMES, Flávio dos Santos. A hidra e os pântanos: mocambos, quilombos e comunidades de fugitivos no Brasil (Séculos XVII-XIX). São Paulo: Ed. UNESP: Ed. Polis, 2005.

GRANET-ABISSET, Anne Marie. O historiador e a fotografia. Tradução de Yara Aun Khoury. Projeto História, n. 24, v. 1, São Paulo, p. 9-26, jun. 2002.

HALL, Stuart. Da Diáspora: identidades e mediações culturais. Tradução Adelaine La Guardiã Resende... [et. al]. Belo Horizonte: Editora UFMG; Brasília: Representação da UNESCO no Brasil, 2003.

HAMPÂTÉ BÂ, Amadou. “A tradição viva”. In: KI-ZERBO (org.) História Geral da África. Vol. 1. São Paulo. Ed. Ática/UNESCO, 1982.

HOGGART, Richard. As utilizações da cultura: aspectos da vida cultural da classe trabalhadora. Vol. 1 e 2. Lisboa: Ed. Presença, 1973.

INGOLD, Tim. Humanidade e animalidade. Revista Brasileira de Ciências Sociais, p. 39-53,1995.

KOSSOY, Boris. Realidades e Ficções na Trama Fotográfica. 2. ed. São Paulo: Ateliê Editora, 2000.

LANDES, Edgar (org.) A colonialidade do saber: eurocentrismo e ciências sociais perspectivas latino-americanas. Tradução Júlio César Casarin Barroso Silva. Buenos Aires: Consejo Latinoamericano de Ciencias Sociales - CLACSO, 2005.

LEÃO, Dione do Socorro de Souza. Deslocamentos e Relações Interculturais na (para a) região de Breves (Arquipélago de Marajó). Texto do Exame de Qualificação da Tese 
de Doutorado em Antropologia. Universidade Federal do Pará, Programa de PósGraduação em Antropologia, 2017.

LEGARDA, Fr. Faustino da Sagrada Família. Relação da Missão de Afuá, Anajás, Chaves, Caviana e Viçosa em 1959. In: BPSTV/OAR. Ano LXI, enero/abril, 1961, num. 400.

LEGARDA, Fr. Faustino Sagrada Família. O que se passou em Afuá, Anajás, Chaves e Caviana em 1960. In: BPSTV/OAR. Ano XLI, enero/abril, 1961, num. 400

LUSTOSA, D. Antônio de Almeida. No estuário Amazônico (“À Margem da Vida Pastoral"). Belém: Conselho Estadual de Cultura, 1976.

LUXARDO, Líbero. Marajó: Terra Anfíbia. Belém: Grafisa, 1977.

MARTÍN-BARBERO, Jesús. Dos meios às mediações: comunicação, cultura e hegemonia. $2^{a}$ edição. Rio de Janeiro: Editora UFRJ, 2001.

MARTÍN-BARBERO. Ofício de cartógrafo: travessias latino-americanas de comunicação na cultura. Tradução Fidelina González. São Paulo: Loyola, 2004.

MAUÉS, Raymundo Heraldo. A Ilha Encantada: medicina e xamanismo numa comunidade de pescadores. Belém: UFPA, 1990.

MAUÉS, Raymundo Heraldo. Padres, pajés, santos e festas: catolicismo popular e controle eclesiástico. Belém: CEJUP, 1995;

MENESES, Ulpiano Bezerra de. Fontes Visuais, Cultura Visual, História. Balanço provisório, propostas cautelares. Revista Brasileira de História, v. 23, n. 45, p. 11-36, 2003.

MIGLIEVICH-RIBEIRO, Adelia. Por uma razão decolonial: Desafios ético-políticoepistemológicos à cosmovisão moderna. Civitas, Porto Alegre, v. 14, n. 1, p. 66-80, jan.abr. 2014.

MIGNOLO, Walter D. Histórias Locais/Projetos Globais: colonialidade, saberes subalternos e pensamento liminar. Tradução de Solange Ribeiro de Oliveira. Belo Horizonte: UFMG, 2003.

MIGNOLO, Walter. Desafios Decoloniais hoje. Epistemologias do Sul, Foz do Iguaçu/PR, v. 1 n. 1, p. 12-32, 2017.

MORAIS, Raimundo. Anfiteatro Amazônico. São Paulo: Melhoramento, 1936.

MORAIS, Raymundo. Na planície Amazônica. São Paulo: Companhia Editora Nacional, 1936.

NELSON, Cary et. al. Estudos Culturais: uma introdução. In: SILVA, Tomaz Tadeu da (org.). Alienígenas na sala de aula: uma introdução aos estudos culturais em educação. 6. ed. Tradução de Tomaz Tadeu da Silva. Petrópolis, RJ: Vozes, 2005, p. 07-38. 
PEIRANO, Mariza. Etnografia e rituais: relato de um percurso. Anuário Antropológico, v. 41, p. 237-248, 2016.

PEIRANO, MARIZA. Etnografia não é método. Horizontes Antropológicos (UFRGS. Impresso), v. 20, p. 377-391, 2014.

PEREIRA, Manoel Nunes. A ilha de Marajó: estudo econômico-social. Rio de Janeiro: Ministério da Agricultura, Serviço de Informação Agrícola em cooperação com a Divisão da Caça e Pesca do DNPA, 1956. (Série Estudos Brasileiros, nº 8)

PEREIRA, Manoel Nunes. Negros Escravos na Amazônia. In: Anais do X Congresso Brasileiro de Geografia, 1944. Rio de Janeiro: IBGE, 1952, v. 3, p. 153-185.

PRANDI, Reginaldo (org.). Encantaria brasileira: O Livro dos Mestres, Caboclos e Encantados. RJ: Pallas, 2001.

PRATT, Mary Louise. Os olhos do Império: relatos de viagem e transculturação. Tradução Jézio Hernani Bonfim Gutierre. Bauru, SP: EDUSC, 1999.

QUIJANO, Aníbal (2000). Colonialidad del poder y clasificación social. Journal of world-systems research, v. 11, n. 2, p. 342-386.

SAMAIN, Etienne. "Ver" e "Dizer" na Tradição Etnográfica: Bronislaw Malinowski e a Fotografia. Horizontes Antropológicos, UFRGS, n. 2, p. 23-60, jul./set. 1995.

SANTOS, Boaventura de Sousa. Para além do pensamento abissal: das linhas globais a uma ecologia de saberes. Novos Estudos-CEBRAP, n. 79, 2007, p. 72.

SARRAF-PACHECO, Agenor. Afroindígena. In: ALBUQUERQUE, Gerson Rodrigues de; SARRAF-PACHECO, Agenor. (org.). UWA'KÜR $\ddot{U}$ : Dicionário Analítico. $1^{\text {a ed.Rio }}$ Branco: Nepan Editora, 2016, v. 1, p. 45-73.

SARRAF-PACHECO, Agenor. Encantarias Afroindígenas na Amazônia Marajoara: narrativas, práticas de cura e (in)tolerâncias religiosas. Horizonte: Revista de Estudos de Teologia e Ciências da Religião (Online), v. 08, p. 88-108, 2010.

SARRAF-PACHECO, Agenor. História e Literatura no Regime das Águas: práticas culturais afroindígenas na Amazônia Marajoara. Amazônica: Revista de Antropologia (Impresso), v. 1, p. 406-441, 2009.

SARRAF-PACHECO, Agenor; SCHAAN, Denise Pahl e BELTRÃO, Jane Felipe (Orgs.). Remando por Campos e Florestas: Patrimônios Marajoaras em Narrativas e Vivências - Ensino Médio. Rio Branco: GKNoronha, 2012

SCHAAN, Denise Pahl, SARRAF-PACHECO, Agenor e BELTRÃO, Jane Felipe (Orgs.). Remando por Campos e Florestas: Memórias \& Paisagens dos Marajós - Ensino Fundamental. Rio Branco: GKNoronha, 2011.

SILVA, Jerônimo da Silva e SARRAF-PACHECO, Agenor. Oralidades em Tempos de Possessões Afroindígenas. História Oral (Rio de Janeiro), v. 15, p. 167-192, 2012. 
SILVA, Jerônimo da Silva e. Cartografia de Afetos na Encantaria: narrativas de mestre da Amazônia Bragantina. Tese (Doutorado em Antropologia), UFPA, 2015.

THOMPSON, Edward Palmer. A miséria da teoria ou um planetário de erros. Rio de Janeiro: Zahar, 1981.

TOCANTINS, Leandro. O rio comanda a vida: Uma interpretação da Amazônia. 8. ed. RJ: Record, 1988.

VERGOLINA E SILVA, Anaíza. O Tambor das Flores: uma análise da Federação Espírita Umbandista e dos Cultos Afro-Brasileiros do Pará (1965-1975). Belém: PakaTatu, 2015[1979].

VERGOLINA E SILVA, Anaíza. Os cultos afros do Pará. In: FONTES, Edilza (org.). Coleção Contando a História do Pará: Diálogos entre História e Antropologia. Vol. III. Belém: E. Motion, 2003, p. 01-34.

WILLIAMS, Raymond. Cultura e sociedade (1780-1950). São Paulo: Editora Nacional, 1969.

WILLIAMS, Raymond. Keywords. Londres: Fontana, 1976. 